\title{
BRACTWA W KOŚCIOŁACH FRANCISZKAŃSKICH W POLSCE W OKRESIE POTRYDENCKIM (XVI-XVIII WIEK)
}

\author{
FRATERNITIES IN THE FRANCISCAN CHURCHES IN POLAND \\ IN THE POST-TRIDENT PERIOD $\left(16^{\text {th }}-18^{\text {th }}\right.$ CENTURIES $)$
}

\begin{abstract}
In the $16^{\text {th }}$ century, the trend of traditional religiosity was developing simultaneously with the top-down Tridentine reform. The dynamism of this trend of popular piety had its source in the late medieval process of deeper penetration of Christianity into the consciousness and life of the general public. This religious trend was expressed in fraternities, which became one of the forms of Catholic revival in Poland after the Council of Trent. The Council of Trent emphasized the fundamental organizational bond of the fraternities with the Church and specified their specificity and subjected them to the direct jurisdiction of the Holy See and the local bishop. A characteristic feature of the fraternities was their universality and omnipotence; members were recruited from people of different classes and professions.

The friars of St. Francis, in the post-Tridentine period, they expanded the area of their social and religious influence, consolidating three new, popular church fraternities at their churches. A reflection of this situation was the Franciscan church in Krakow, next to which in the $16^{\text {th }} / 17^{\text {th }}$ century were founded three typical Franciscan fraternities: the Cord of St. Francis (1587), the Passion of Christ (1595), St. Anthony (1664). The fraternities took advantage of the spiritual direction of the Franciscan friars and enjoyed numerous privileges and indulgences that the friars were seeking. The activity of fraternities in Franciscan churches was a characteristic phenomenon of Catholic renewal after the Council of Trent. The Franciscans, along with other Mendicant orders, entered this trend in an impressive way, because thanks to their commitment and work, the integration of social groups on the religious, spiritual, cultural and charitable level contributed to the renewal of the Church and Polish society.
\end{abstract}

Keywords: archconfraternity; fraternity; Saint Francis of Assisi; Saint Anthony of Padua; Franciscans; indulgences.

Dr ADAM MĄCZKa OFMConv - doktor teologii w zakresie historii Kościoła; Papieski Wydział Teologiczny Św. Bonawentury w Rzymie; adres do korespondencji: Via Del Serafico, 1; 00142 Roma; e-mail: adamobot@yahoo.com; ORCID: https://orcid.org/0000-0002-6674-7807. 
Bardzo szybki rozwój bractw kościelnych w Polsce, podobnie jak w całym Kościele katolickim, nastąpił w okresie odnowy trydenckiej. We wspomnianym okresie bractwa stały się ważnym czynnikiem odnowy religijnej po reformacji. Przeciwdziałanie naporowi innowierców wymagało dokształcania religijnego wiernych, dlatego w tym celu stworzono bractwa katechetyczne. W XVII i XVIII wieku zakładano bractwa pogrzebowe i dobrej śmierci, jak również liczne bractwa charytatywno-kultowe i ascetyczno-kultowe pod patronatem Matki Boskiej Bolesnej, Pośredniczki i Wspomożycielki lub pod wezwaniem świętych patronów oraz bractwa pasyjne. Były one odpowiedzią na konkretne błędy doktrynalne, a od XVI wieku odgrywały również coraz większą rolę jako pomoc dla misjonarzy w chrystianizacji nowo odkrywanych części świata ${ }^{1}$.

Rozwój bractw w końcu XVI oraz w XVII i XVIII w. dokonywał się również w ścisłym związku z rozwojem kultu maryjnego i kultów świętych, propagowanych zwłaszcza przez zakony. Dużą rolę odegrał tu szerzący się kult obrazów oraz coraz liczniejsze pielgrzymki do miejsc słynących cudami ${ }^{2}$.

Na przełomie XVI i XVII w. przy wielu kościołach franciszkańskich w Polsce powstało lub inicjowało swoją działalność jakieś bractwo. W pewnym sensie stało się to nową formą pracy duszpasterskiej franciszkanów, gdyż liczne bractwa kościelne wymagały opieki duchowej, co zresztą jasno określało prawodawstwo kościelne i zasady funkcjonowania bractw kościelnych przy kościołach parafialnych i zakonnych.

Zgodnie $\mathrm{z}$ prawem kościelnym erygowanie bractw kościelnych należało do Stolicy Apostolskiej ${ }^{3}$ i biskupa miejsca ${ }^{4}$. Władza ordynariusza na erygowanie bractw zakonnych była ograniczona ze względu na specjalne przywileje, które papieże nadawali zakonom. Erygowanie bractw zakonnych zarezerwowane było dla wyższych przełożonych zakonnych, oczywiście mogli to czynić jedynie przełożeni, którym taki przywilej został udzielony przez Stolicę Apostolską. Wtedy tylko Generał danego zakonu mógł na mocy udzielonego przywileju erygować arcybractwo lub bractwo we wszystkich kościołach, kaplicach publicznych i kaplicach półpublicznych. Do erygowania wymagana jednak była zgoda biskupa miejsca. W przypadku zakładania arcybractwa niezorganizowanego przy kościołach klasztornych nie było konieczne nowe

\footnotetext{
${ }^{1}$ Krystyna Kuźmak, „Bractwo kościelne”, w Encyklopedia Katolicka, t. 2, red. Feliks Gryglewicz, Romuald Łukaszyk, Zygmunt Sułowski (Lublin: Towarzystwo Naukowe KUL, 1985), 1013.

${ }^{2}$ Stanisław Litak, „Bractwa religijne w Polsce przedrozbiorowej XIII-XVIII wiek. Rozwój i problematyka", Przeglad Historyczny 88(1997),3-4: 499-523.

${ }^{3}$ Codex iuris canonici auctoritate Ioannis Pauli PP. II promulgatus (25 Ianuarii 1983), w: Acta Apostolicae Sedis 75(1983-II), 65-68 (Can. 250. §2 i Can. 252).

${ }^{4}$ Tamże, 204 (Can. 686).
} 
pozwolenie biskupa, lecz wystarczało to, które zezwalało na założenie klasztoru. Jednak do erygowania bractwa posiadającego własny zarząd, wymagana była zgoda ordynariusza na piśmie ${ }^{5}$.

Bractwa lub arcybractwa powstawały przy kościołach klasztornych z inicjatywy przełożonych zakonnych. Organizacja nowego bractwa miała na celu pobudzenie pobożności wiernych i odbywała się zazwyczaj w podobny sposób. Gdy pojawiła się grupa pobożnych niewiast lub mężczyzn, którzy mogli się podjąć organizacji bractwa, na początku promotor (najczęściej przełożony klasztoru) odpowiednio przygotowywał od strony formacyjnej kandydatów, przedstawiając im cele, obowiązki i przywileje przynależności do bractwa. Jeżeli chętni wyrażali zgodę, to zwracano się o stosowne pozwolenia do biskupa miejsca i generała zakonu. Następnie ogłaszano nabór członków, którym przedstawiano zasady przystępowania do bractwa oraz formy działalności we wspólnocie. Sam fakt erygowania bractwa przy kościele odbywał się w sposób uroczysty najczęściej podczas Mszy św., z odczytaniem dekretu erekcyjnego, okolicznościowym kazaniem i Komunią św. Po ustanowieniu bractwa oraz odpowiednim przygotowaniu nowych członków, promotor przyjmował i wpisywał ich do specjalnej księgi brackiej. Przyjmowaniu nowych członków bractwa towarzyszyło wręczenie specjalnego stroju lub znaków przynależności do bractwa. Często przyjmowanie nowych członków odbywało się podczas nabożeństwa przy brackim ołtarzu lub w specjalnej kaplicy przeznaczonej do nabożeństw bractwa ${ }^{6}$.

Działalność bractw przy kościołach zakonnych była związana przede wszystkim z duchowością zakonu. Konstytucje zakonne zobowiązywały przełożonych do szczególnej troski związanej z opieką i rozwojem ruchu brackiego. Bractwa, powstałe przy kościołach zakonnych (np. franciszkańskich lub dominikańskich), propagowały w danym miejscu religijność i duchowość charakterystyczną dla zakonu, kult świętych pochodzących z tego zakonu oraz były pomocą w pracy duszpasterskiej zakonów. W praktyce każdy ówczesny zakon posiadał przywilej do erygowania bractwa typowego dla swojego zakonu, nie tylko w swoich kościołach, ale również w kościołach innych zakonów oraz w kościołach diecezjalnych. Zapewniały to przepisy kościelne z początku XVII w. Ważną w tym zakresie stała się bulla papieża Klemensa VIII Quaecumque z 7 grudnia 1604, która nawiązując do poprzednich rozporządzeń papieskich, wprowadziła nowy porządek w ruch bracki, a przez to

\footnotetext{
${ }^{5}$ Mirosław Kuczkowski, „Arcybractwo Paska św. Franciszka z Asyżu w Polsce na przestrzeni wieków”, Teologia i Człowiek 22(2013), 2: 52.

${ }^{6}$ Tamże, 53.
} 
stała się podstawą rozwoju bractw w okresie nowożytnym. Istotnym postulatem bulli z 1604 r. było zezwolenie zakonom na erygowanie bractw typowo zakonnych przy kościołach parafialnych i przy kościołach innych zakonów. W Polsce konstytucję tę wprowadził w życie biskup krakowski Marcin Szyszkowski na synodzie krakowskim w $1621 \mathrm{r}$. precyzując warunki, na jakich można było zaprowadzać bractwa po kościołach. Tak więc bractwa zaczęły powstawać na dużą skalę, czasami kilka przy jednym kościele. Zakony zaczęły odgrywać pierwszorzędną rolę w ich rozwoju i prosperowaniu, ponieważ oprócz opieki duchowej starały się o liczne przywileje, z których korzystali nie tylko członkowie bractw, ale również wierni, którzy dzięki tym przywilejom licznie przybywali do kościołów zakonnych. Bractwa stały się więc, jak już było powiedziane, dużym pożytkiem w działalności duszpasterskiej zakonów. Ich fundatorami i dobrodziejami byli: król, biskup, duchowieństwo, szlachta i mieszczanie. Każde bractwo otrzymując odpowiednie odpusty, nadawane przez papieży lub biskupów na mocy indultu papieskiego, jeszcze bardziej przyciągało wiernych do przynależności i działalności w bractwie. Dążono do upowszechnienia bractw w społeczeństwie oraz kontrolowano je przy okazji wizytacji klasztorów ${ }^{7}$.

W XVII i XVIII w. funkcjonowało w Polsce ok. 80 typów bractw. Najliczniejsza była grupa bractw dewocyjnych, którą z kolei, przyjmując za kryterium wezwania poszczególnych bractw, można podzielić na pięć podgrup: 1) bractwa o wezwaniach odwołujących się do Boga Trójjedynego (Świętej Trójcy, Opatrzności Bożej, Bożego Miłosierdzia, Imienia Bożego); 2) bractwa o wezwaniach chrystologicznych (Bożego Ciała, Compassionis, Grobu Jerozolimskiego, Imienia Jezus, Jezusa Konającego, Lęku Jezusa, Męki Pańskiej, Miłośników Krzyża, Pana Jezusa Nazareńskiego, Dzieciątka Jezus, Pięciu Ran Pana Jezusa, Przemienienia Pańskiego, Serca Jezusowego, Świętego Krzyża, Ukrzyżowania Pana Jezusa); 3) bractwa o wezwaniach maryjnych (Matki Boskiej Królowej Polski, Matki Boskiej Jasnogórskiej, NMP Bolesnej, NMP Łaskawej, Imienia Marii, Literackie NMP, NMP, Ofiarowania NMP, Niepokalanego Poczęcia NMP, Pocieszenia NMP, Porcjunkuli, Roratnie, Różańca Świętego, Siedmiu Boleści NMP, Szkaplerza Świętego, Wniebowzięcia NMP, Wspomożenia NMP, Zwiastowania NMP); 4) bractwa o wezwaniach anielskich (Aniołów Stróżów, Michała Archanioła) oraz 5) bractwa o wezwaniach poszczególnych świętych (Alojzego, Andrzeja, Antoniego Padewskiego, Augustyna i Moniki, Barbary, Cecylii, Iwona, Izydora Oracza, Jakuba, Jana Nepomucena, Jerzego, Jozafata, Józefa, Judy Tadeusza,

${ }^{7}$ Litak, „Bractwa religijne w Polsce”, 510-511. 
Marcina, Marii Magdaleny, Mikołaja, Paska św. Augustyna, Paska św. Franciszka z Asyżu, Paska św. Tomasza z Akwinu, Rocha, Stanisława bpa, Tekli, Świętej Rodziny, Urszuli, Walentego, Wawrzyńca). Do bractw charytatywnych można zaliczyć bractwa: kapłańskie, miłosierdzia wraz z bankami pobożnymi, niemieckie oraz bractwa ubogich. Do grupy ,innych” zaliczono bractwa: biczowników, Braci NMP, dobrej śmierci, muzyków, rolników oraz bractwa strzeleckie nazywane kurkowymi ${ }^{8}$.

Popularność bractw sprawiła, że ze strony zakonów było duże zainteresowanie, aby uzyskać papieski przywilej do erygowania bractwa typowego dla danego zakonu. Takie przywileje zakładania bractw posiadali dominikanie (typowym bractwem dla dominikanów było bractwo różańcowe, przez nich zakładane), bernardyni (bractwo św. Anny), karmelici (bractwo Szkaplerza NMP). Franciszkanie natomiast zasłynęli w Polsce z zakładania przy swoich kościołach trzech bractw, na które mieli papieskie pozwolenie na ich erygowanie nie tylko przy kościołach franciszkańskich, ale również przy kościołach innych zakonów i kościołach parafialnych. Były to bractwa: Bractwo Paska św. Franciszka z Asyżu, Bractwo św. Antoniego Padewskiego oraz Bractwo Męki Pańskiej9.

\section{BRACTWO PASKA ŚW. FRANCISZKA}

Bractwo Paska św. Franciszka (Confraternitas Chordigerorum) zostało ustanowione w dniu 19 listopada 1585 r., w randze arcybractwa, przez papieża Sykstusa V, bullą Ex supernae dispositionis, przy bazylice grobu św. Franciszka w Asyżu. Nazwa bractwa pochodziła od chordum, czyli od paska poświęconego na cześć św. Franciszka, który członkowie byli zobowiązani nosić. Arcybractwo było ściśle związane z gałęzią franciszkanów konwentualnych (OFMConv). Generał zakonu franciszkańskiego otrzymał od Stolicy Apostolskiej prawo erygowania Bractwa Paska św. Franciszka w poszczególnych krajach oraz agregowania ich do Arcybractwa w Asyżu. Ten sam papież bullą Divinae caritatis z 29 sierpnia 1587 r. udzielił Arcybractwu nowych odpustów i upoważnił Ministra Generalnego Obserwantów do erygowania bractw św. Paska w kościołach własnego Zakonu, w miejscach, gdzie nie było Konwentualnych. Podobne uprawnienia papież Grzegorz XV nadał w dniu 27 czerwca 1622 r.

\footnotetext{
${ }^{8}$ Tamże, 517.

${ }^{9}$ Kamil Kantak, Franciszkanie polscy, t. 2 (Kraków: Prowincja Polska OO. Franciszkanów, 1938), 288.
} 
Ministrowi generalnemu Trzeciego Zakonu Regularnego, a papież Pius X, poprzez reskrypt Świętej Kongregacji Odpustów z 14 grudnia 1904 r., Ministrowi Generalnemu Kapucynów. Papież Paweł V bullą Cum certas z 2 marca 1607 r. oraz bullą Nuper Archiconfraternitati z 11 marca 1607 r. odwołał wszystkie duchowe łaski przyznane dotychczas Arcybractwu, wzbogacając je o nowe i szersze odpusty. Oba te akty zostały potwierdzone przez papieża Klemensa X przez brewe Dudum felicis z 13 lipca 1673 r. Papież Benedykt XIII w swojej konstytucji Sacrosancti apostolatus z 30 września 1724 r. nadał Ministrowi generalnemu Konwentualnych upoważnienie do erygowania bractw św. Paska w kościołach nienależących do jego własnego Zakonu, w miejscach, gdzie nie było franciszkanów innych gałęzi. Nowe przywileje i odpusty zostały nadane Arcybractwu dwoma dekretami Świętej Kongregacji Odpustów z 22 marca 1879 roku i 26 maja 1883 roku $^{10}$.

Bractwo bardzo szybko rozpowszechniło się po kościołach franciszkańskich w całej Europie. W Polsce pierwsze bractwo Paska św. Franciszka założył w 1586 r. prowincjał Jerzy Benigny De Doinois Bellunensis ${ }^{11}$ przy kościele franciszkanów w Krakowie. Zostało agregowane w tym samym roku do arcybractwa asyskiego na podstawie bulli papieża Sykstusa V z 1586 r., na mocy której generał franciszkanów konwentualnych mógł zakładać przy wszystkich kościołach franciszkańskich bractwo Paska św. Franciszka. Bulla dawała prawo do agregowania czcicieli św. Franciszka, zorganizowanych w stowarzyszenie, do arcybractwa w Asyżu nadając im w ten sposób pełne prawa i przywileje należne członkom asyskiego arcybractwa. Już w 1597 roku przetłumaczono i wydrukowano przywileje i odpusty brackie. W 1603 roku nuncjusz papieski Klaudiusz Rangoni (1598-1607) zezwolił na organizowanie procesji z Najświętszym Sakramentem przy wszystkich kościołach, gdzie założone było arcybractwo. Bractwo ze swoimi przywilejami było bardzo popularne oraz popierane przez biskupów i królów. Należeli do niego m.in.: abp lwowski J. Solikowski, król Zygmunt III Waza i jego syn Władysław ${ }^{12}$. Szybko rozpowszechniło się po całym kraju, nowe wspólnoty powstały w: Lwowie,

\footnotetext{
${ }^{10}$ Pietro Chiminelli, L'umile capestro. La corda francescana (Padova, Edizioni il Messaggero di Sant'Antonio, 1957), 82.

${ }^{11}$ Prowincjał w latach 1583-86, zob. Alojzy Karwacki, Materiaty do historii polskiej i ruskiej prowincji oo. Franciszkanów, t. 7, Archiwum Franciszkanów w Krakowie (dalej AFK), sygn. E-I-7, 305-8; Kantak, Franciszkanie polscy, 188.

${ }^{12}$ Krystyna Kuźmak, „Św. Franciszek z Asyżu - Bractwa”, w Encyklopedia Katolicka, t. 5, red. Ludomir Bieńkowski, Piotr Hemperek, Stanisław Kamiński, Jerzy Misiurek, Krystyna Stawecka, Antoni Stępień, Adam Szafrański, Jan Szlaga, Anzelm Weiss (Lublin: Towarzystwo Naukowe KUL, 1989), 433-434; Kantak, Franciszkanie polscy, 289-291.
} 
Gnieźnie (1587) ${ }^{13}$, Radziejowie, Kaliszu (1603) ${ }^{14}$, Grabowie (1632) ${ }^{15}$, Pyzdrach $(1610)^{16}$, Warce ${ }^{17}$, Krośnie (1603), Lublinie $(1622)^{18}$, Nieszawie $(1626)^{19}$, Bełchatowie, Smardzewicach $(1642)^{20}$, Warszawie $(1650),{ }^{21}$ Kalwarii Pacławskiej $^{22}$, Starym Sączu $(1693)^{23}$, Stężycy oraz przy innych klasztorach franciszkańskich.

Członkowie bractwa Paska św. Franciszka zobowiązani byli nosić biały sznur, symbolizujący zjednoczenie się z Jezusem podczas Jego męki. Sznur również symbolizował cnoty, którymi członkowie powinni kierować się w swoim życiu, a mianowicie czystość i wstrzemięźliwość. Chociaż często naśmiewano się z noszonego paska przez braci, to jednak zalecano, aby go nosić w dzień i w nocy, jak podaje Liricius w swoim podręczniku z 1625 r.: „rzecz przystoynieysz nosić go z zwierzchu [...], sypiać albo blisko tóżka powieszać dla obrony przeciwko pokusom" ${ }^{24}$. Nawet po śmierci brata, podczas modlitw za niego, pasek kładziono do trumny. Statuty arcybractwa zobowiązywały członków do modlitw brackich, wspólnych nabożeństw i innych praktyk ascetycznych. Zachęcano członków do częstej spowiedzi i Komunii św. W każdą trzecią niedzielę miesiąca bractwo brało udział we Mszy św. śpiewanej o św. Franciszku, w nabożeństwie ku jego czci, w procesji z Najświętszym Sakramentem, która najczęściej odbywała się rano. Po południu bracia zbierali się w kościele

\footnotetext{
${ }^{13}$ Gnieźnieńskie bractwo Paska św. Franciszka należało do najstarszych w Polsce, założone zostało 19 maja 1587 i potwierdzone przez generała zakonu Ewangelistę Pelleo. Bonawentura Makowski, Thesaurus Provinciae Poloniae O.M.S.F.C. A.D. 1764, Archiwum Franciszkanów w Warszawie (dalej AFW), sygn. VIII/5, 534.

${ }^{14}$ Makowski, Thesaurus Provinciae Poloniae, 461.

${ }^{15}$ Tamże, 417.

${ }^{16}$ Tamże, 464.

${ }^{17}$ Tamże, 13.

${ }^{18}$ Tamże, 29.

${ }^{19}$ Tamże, 617; Jakub Piasecki, Opisanie kościołów i klasztorów księży franciszkanów (konwentualnemi zwanych): z dawnej prowincyi Polskiej Ś. Franciszka Seraficznego po utworzeniu w r. 1815 Królestwa Polskiego pozostałych / przez Jakóba Piaseckiego, (Warszawa: Drukarnia J. Glücksberga, 1845), 104.

${ }^{20}$ Tamże, 148.

${ }^{21}$ Makowski, Thesaurus Provinciae Poloniae, 668; Piasecki, Opisanie kościołów i klasztorów księży franciszkanów, 214.

${ }_{22}$ Symeon Barcik, Kalwaria Pactawska (Warszawa: Akademia Teologii Katolickiej, 1985), 137.

${ }^{23}$ Stanisław Lelito, Historia klasztoru Franciszkanów w Starym Sączu (1280-1815), (Kraków: Biblioteka Franciszkanów [mps], 2009), 100-102.

${ }^{24}$ Hipolit Liricius, Bractwo chordy abo paska zakonnego s. Franciszka po wszytkiey Koronie Polskiey v Braciey Mnieyszych Franciszka s. moca stolice apostolskiey postanowione [...]; z Sporzadzeniem nabożeństwa ktore zwykło bywać na mszach y processyach brackich, z niektoremi modlitwami (Kraków: W drukarniey Waleryana Piątkowskiego: [nakł. Bractwa św. Franciszka], 1646); cyt. za: Kantak, Franciszkanie polscy, 290.
} 
na naukę oraz na nieszpory, dzięki którym mogli uzyskać odpust zupełny. Podczas nabożeństw i procesji śpiewano pieśni oraz odmawiano modlitwy ku czci św. Franciszka, np. Pieśń o stońcu lub Hymn św. Bonawentury ${ }^{25}$. Jeden raz w roku organizowano nabożeństwo żałobne za zmarłych członków bractwa, w którym brali udział wszyscy bracia. Podobnie wszyscy członkowie uczestniczyli w pogrzebie zmarłego brata.

Podstawowym celem bractwa była działalność apostolska, charytatywna oraz społeczna. Zasadami życiowymi braci było przebaczenie nieprzyjaciołom oraz uczynki miłosierdzia. W szczególny sposób opiekowano się ubogimi, chorymi oraz tymi braćmi, którzy potrzebowali pomocy. Wybierano nawet specjalnych infirmarzy, którzy mieli odwiedzać chorych w ich domach: „a jeśli by (brat) tak ubogi był, żeby się pożywić nie mógł, powinni powiedzieć o. gwardianowi y przyorowi a w niebytności jego consyliarzom, oni zaś starać się mają, jako by naylepiey zapomocy ratować go mogli z skrzynki brackiej"26. Bractwo było bardzo dobrze zorganizowane strukturalnie. Co roku, w drugi dzień Zielonych Świąt, bractwo zbierało się na wybór zarządu, w skład którego wchodzili: przeor, 2 kustoszów, 2 podskarbich, 2 sekretarzy, 4 infirmarzy, 2 pacyfikarzy. Również kobiety, należące do bractwa, wybierały sobie ,jednę matkę y dwie conserwatryczki" oraz kobiety na inne urzędy ${ }^{27}$. Bractwo dysponowało swoimi funduszami, które pochodziły prawdopodobnie ze składek do tzw. skrzynki brackiej. Funduszami tymi wspomagano potrzebujących, szczególnie konfratrów. Promotorem bractwa mógł być tylko kapłan. W klasztorach franciszkanów funkcję tę przeważnie pełnił przełożony wspólnoty zakonnej lub wyznaczony przez niego inny kapłan zakonny. W parafiach niezakonnych promotorem bractwa mógł być kapłan mianowany przez wyższego przełożonego zakonnego, za uprzednią zgodą biskupa miejsca. Generał miał prawo w ważnym przypadku, w porozumieniu z biskupem diecezjalnym, do odwołania promotora arcybractwa $\mathrm{z}$ jego funkcji. Promotor po objęciu funkcji w bractwie miał prawo do wpisywania kandydatów do księgi członkowskiej, przekazywania dyplomów bractwa, błogosławieństwa paska i wręczania go nowym członkom. W powyższych czynnościach promotor nie mógł być zastępowany przez innych kapłanów lub delegatów. Do niego należało kierowanie bractwem, dbanie o przestrzeganie karności, troska o rozwój i wzrost

\footnotetext{
${ }^{25}$ Tak podaje w swoim podręczniku Liricius, Bractwo chordy; cyt. za: Kantak, Franciszkanie polscy, 291: „Hymnu św. Bonawentury: Ozdoba cnot, wodz mnieyszych rot; Franciszek już wiekuiste; Ma pałace za swe prace; Przez cię, Zbawicielu Chryste".

${ }^{26}$ Liricius, Bractwo chordy; cyt. za: Kantak, Franciszkanie polscy, 290.

${ }^{27}$ Tamże, 290, 291.
} 
duchowy, a także głoszenie konferencji oraz zwoływanie zebrań i prowadzenie nabożeństw brackich ${ }^{28}$.

Bractwo Paska św. Franciszka cieszyło się popularnością wśród wiernych. Z dokumentów archiwalnych z XVII i XVIII w. oraz z analiz przeprowadzonych przez historyków ${ }^{29}$ wynika, że $\mathrm{w}$ ciągu wieków arcybractwo zostało obdarzone przez Stolicę Apostolską licznymi odpustami i łaskami ${ }^{30}$. Warunki konieczne do uzyskania odpustów i łask przedstawiały się następująco: 1) wpisanie się do arcybractwa i noszenie paska; 2) spowiedź i Komunia św.; 3) przy nawiedzeniu kościoła odmówienie 6 Ojcze nasz, 6 Zdrowaś Maryjo i 6 Chwała Ojcu. W przypadku osób, które korzystały ze spowiedzi 2 razy w ciągu miesiąca lub przystępowały codziennie do Komunii św., nie musiały dodatkowo się spowiadać, aby uzyskać odpust. Inne osoby mogły odprawić spowiedź 6 dni przed terminem odpustu, a komunię przyjąć w wigilię, wyznaczony dzień lub oktawę uroczystości odpustu. Wyszczególniono odpusty zupełne i cząstkowe. Odpusty zupełne można było uzyskać w następujących okolicznościach $\left.{ }^{31}: 1\right) \mathrm{w}$ dniu wstąpienia do arcybractwa i przyjęcia paska; 2) każdego roku w uroczyste święta brackie, przez nawiedzenie kościoła lub kaplicy, w których założone było arcybractwo i modlitwy w intencji papieża; 3) w godzinę śmierci za pobożne wymówienie Imienia Jezus po spowiedzi i Komunii św. lub po wzbudzeniu żalu doskonałego; 4) za uczestniczenie w comiesięcznych procesjach brackich, po spowiedzi i przyjęciu Komunii św.; 5) przy nawiedzeniu kościoła brackiego od południa 1 sierpnia do północy 2 sierpnia. Oprócz powyższych odpustów członkowie arcybractwa mogli uzyskać odpusty cząstkowe za wypełnienie następujących praktyk: 1) uczestniczenie w miesięcznych procesjach brackich, bez spowiedzi i Komunii św. - 3 lata i 3 kwadragen; 2) uczestniczenie w oficjum o Matce Bożej, a także w każdym innym oficjum - 100 dni; 3) za towarzyszenie kapłanowi z Najświętszym Sakramentem podczas drogi do chorego - 5 lat i 5 kwadragen; 4) po spowiedzi i Komunii św. za nawiedzenie kościoła braci mniejszych franciszkanów i odmówieniu modlitwy w intencji papieża, w następujące uroczystości: św. Franciszka, św. Antoniego, św. Klary,

28 „Arcybractwo Paska św. Franciszka”, Wiadomości Tercjarskie 28(1936): 116; „Arcybractwo Paska św. Franciszka", Pochodnia Seraficka 3(1936): 91.

${ }^{29}$ Kuczkowski, „Arcybractwo Paska św. Franciszka”, 43-60.

${ }^{30}$ „Arcybractwo Paska św. Franciszka”, 91. W ciągu wieków papieże szczodrze obdarzali Arcybractwo Paska Św. Franciszka łaskami i odpustami: Sykstus V, Paweł V, Klemens X i Leon XIII. Odpusty te zebrane są w brewe Klemensa X Dudum felicis z r. 1673. Zatwierdziła je św. Kongregacja Odpustów i uznała za autentyczne 1 czerwca 1866.

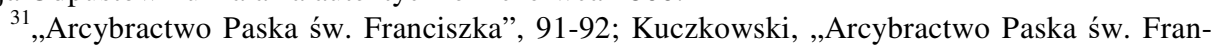
ciszka", 56-57. 
Stygmatów św. Franciszka, św. Dydaka, św. Piotra z Alkantry, św. Męczenników Zakonu, św. Elżbiety Węgierskiej - 7 lat i 7 kwadragen $^{32}$; 5) za udział w pogrzebach, pomoc biednym, wspomaganie zwaśnionych - 100 dni. Inne przywileje: 1) w uroczystości św. Franciszka z Asyżu, św. Klary, św. Antoniego z Padwy, Stygmatów św. Franciszka zyskują specjalne uczestnictwo w łaskach i błogosławieństwach udzielonych zakonowi franciszkańskiemu za dobre uczynki oraz zasługi jego członków; 2) w uroczystość Niepokalanego Poczęcia N.M.P członkowie otrzymują specjalne błogosławieństwo papieskie ${ }^{33}$.

Najbardziej aktywne było bractwo krakowskie. Od samego początku zyskało wielu zacnych członków z rodzin szlacheckich i mieszczańskich, ale również jego promotorami byli franciszkanie z krakowskiego konwentu. Jednym z nich na początku istnienia bractwa był Liricjusz vel Liricius Hipolit. W 1602 roku przebywał w konwencie krakowskim, gdzie został lektorem w studium zakonnym w Krakowie i wkrótce potem promotorem Bractwa Paska św. Franciszka. Jego działalność pisarska związana była z tą posługą. Pierwszym jego dziełem była książeczka pisana wierszem pt. Wzory cnót albo przedziwny żywot anielskiego i błogostawionego św. Franciszka (Kraków 1594 i 1608). Ze względu na popularność doczekała się dwóch wydań (choć pierwsze wydanie niektórzy historycy przypisują komu innemu $)^{34}$. Od 1606 r. Liricjusz wydawał dziełko ascetyczne pt. Bractwo Chordy albo Paska zakonnego św. Franciszka (Poznań 1606 - pierwsze wydanie). Książeczka służyła jako lektura duchowa i modlitewnik dla członków bractwa. Była to bardzo popularna i poczytna pozycja książkowa, skoro doczekała się kilkunastu wydań po polsku i po łacinie. Książeczka oprócz dedykacji zawierała krótką historię powstania bractwa, okoliczności sprowadzenia bractwa do Polski, wymieniała wszystkie nadane odpusty i przywileje dla braci przez papieży Pawła V i Sykstusa V. Zawierała ceremonię przyjęcia do bractwa, wymieniała obowiązki i zadania bractwa, nakreślała porządek nabożeństw brackich oraz wyliczała jakie odpusty mogli zyskać bracia. Ważną częścią książki były teksty modlitw i medytacji, m.in. „koronka Zbawiciela Chrystusa; koronka Maryi; rozmyślania na 15 pacierzy;

\footnotetext{
${ }^{32}$ Quadragena (łac.), kwadragena surowy post czterdziestodniowy, praktykowany w pierwotnym chrześcijaństwie. Do pokuty publicznej dołączano post, np. siedem lat i siedem kwadragen, znaczy pokutując 7 lat i poszcząc 7 kwadragen. „Odpustu 7 lat i tyleż kwadragen” oznaczało 7 razy po 40 dni, czyli odpust 280 dni.

33 „Arcybractwo Paska św. Franciszka”, 91-92.

${ }^{34}$ Liricjusz vel Liricius Hipolit (ur. ok. 1572, zm. po 1625), franciszkanin, pisarz, thumacz, autor dzieł ascetycznych, kustosz, pochodził ze Starego Sącza. Zob. Kantak, Franciszkanie polscy, 250. (K. Kantak twierdzi, że dzieło było tłumaczeniem nieznanego autora i przypisuje go bernardynowi, stąd pierwsza edycja z 1594 - jego zdaniem - została wydana przez bernardynów).
} 
modlitwy za braci oraz litania". Ostatnie wydanie tej popularnej wówczas pozycji miało miejsce w 1631 r. Na zakończenie swojej działalności pisarskiej Lirycjusz wydał zbiór nabożeństw dla bractwa Paska św. Franciszka, pt. Fasciculus triplex confraternitatis chordigerorum S. Francisci ex piis ac devotis exercitiis in gratiam confratrum eiusdem sodalitii (Kraków 1617) ${ }^{35}$.

Na początku XVII w. przy wielu świątyniach franciszkańskich w Polsce powstały bractwa Paska św. Franciszka. Na przykładzie bractwa Paska św. Franciszka przy kościele franciszkanów w Krośnie można zobaczyć, jak bractwo funkcjonowało w ówczesnych realiach. W Krośnie oficjalnie bractwo rozpoczęło swoją działalność 30 września 1603 r. W akcie erekcyjnym Minister Generalny Braci Mniejszych Konwentualnych o. Josephus Pisculius ${ }^{36}$ powołując się na bullę papieża Sykstusa V z 1586 r., na mocy której generał konwentualnych mógł zakładać przy wszystkich kościołach bractwo Paska św. Franciszka, agregował czcicieli św. Franciszka do Arcybractwa w Asyżu nadając im w ten sposób pełne prawa i przywileje należne członkom arcybractwa ${ }^{37}$. Generał, przebywając w Krakowie pozwolił na działalność bractwa Paska św. Franciszka jeszcze przy kliku innych klasztorach franciszkańskich w Polsce, gdyż dokumenty erekcyjne są datowane na wrzesień 1603 r., a miejscem datowania jest Kraków ${ }^{38}$. Oprócz Krosna, takie pozwolenia otrzymały bractwa: Kalisz ${ }^{39}$, Pyzdry ${ }^{40}$.

Wizytujący klasztor prowincjał Jan Romartovii w 1609 r. potwierdza istnienie bractwa w Krośnie, gdyż wymienia dwie chorągwie z wizerunkiem św. Franciszka i innych świętych franciszkańskich ${ }^{41}$. Wzmiankę o działalności bractwa przy

${ }^{35}$ Karol Estreicher, Bibliografia polska, t. XXI (Kraków: Wyd. Stanisław Estreicher, 1913), 328-329; Kantak, Franciszkanie polscy, 250-251; Edward Ozorowski, „Lirucjusz Hipolit”, w Stownik Polskich Pisarzy Franciszkańskich, red. Hieronim Wyczawski (Warszawa: Archiwum Prowincji OO. Bernardynów, 1981), 279-280; Giovanni Franchini, Bibliosofia e memorie letterarie di scrittori Francescani conventuali (Modena: Per gli eredi solani stampatori duch. 1693), 378.

${ }^{36}$ Fr. Josephus Pisculius z Melfi (Apulia - Włochy) piastował urząd Ministra Generalnego w latach 1602-1607. Przebywał w Polsce w 1603 r. na kapitule prowincjalnej, z tej okazji erygował kilka bractw przy franciszkańskich kościołach.

${ }^{37}$ Akt erekcyjny Arcybractwa Paska św. Franciszka. Archiwum Franciszkanów w Krośnie (dalej AFKr), sygn. A 2 pap. 1586. Akt posiada pieczęć owalną generała, wyciśniętą w laku z napisem w otoku: „Sigilium Ministri Generalis totius Ordinis Fratrum Minorum”; został wystawiony w Krakowie, dnia 30 września 1603 r., obok daty widnieje podpis generała. Bractwo Paska św. Franciszka w Krośnie zostało zatwierdzone przez biskupa przemyskiego Macieja Pstrokońskiego, urzędował w latach 1601-1609 (stąd na dokumencie jest jego ,admissio” i pieczęć).

${ }^{38}$ Makowski, Thesaurus Provinciae Poloniae, 459.

${ }^{39}$ Fr. Josephus Pisculius z Melfi (Apulia - Włochy piastował urząd Ministra Generalnego w latach 1602-1607.

${ }^{40}$ Piasecki, Opisanie kościołów i klasztorów księży franciszkanów, 86-87.

${ }^{41}$ Inventarium rerum et bonorum omnium Ecclesiarum de Conventum totius Provinciae Regni Poloniae et M. D. Lithuaniae sub felici administratione A.R.P. Joannis Romartovii Artium et S.T.D. 
kościele franciszkanów w Krośnie spotykamy w aktach wizytacyjnych prowincjała Adama Goskiego z 1612 roku $^{42}$. Krośnieńscy franciszkanie w celu zachęcenia wiernych, aby jak najliczniej wpisywali się w szeregi bractwa i uczestniczyli w praktykach pobożnych konfraterni, postarali się o szczególne przywileje i odpusty dla członków bractwa. W 1628 r., w święto św. Franciszka z Asyżu, o. Felix Franceschinus de Cassia ${ }^{43}$, Minister Generalny OFMConv, zatwierdził braciom i siostrom konfraterni Paska św. Franciszka w Krośnie, przy kościele Nawiedzenia NMP, odpusty nadane przez papieża Sykstusa V arcybractwu. Członkowie arcybractwa mogli uzyskać następujące odpusty: odpust zupełny w dzień wstąpienia do arcybractwa; odpust za udział w procesjach, odprawianych co miesiąc przez bractwo; odpust toties, quoties et in articulo mortis, czyli wiele razy i w godzinie śmierci, za wymówienie Imienia Jezus; 100 dni odpustu za towarzyszenie kapłanowi idącemu z wiatykiem do chorego; odpust za odprowadzenie zmarłego do grobu. Mogli korzystać ponadto z wszystkich odpustów nadanych zakonowi św. Franciszka ${ }^{44}$. Bractwo najprawdopodobniej miało swój ołtarz w kościele ku czci św. Franciszka, przy którym odprawiano nabożeństwa. Potwierdzeniem tego może być krótka wzmianka z księgi wydatków, w której dnia 3 października 1680 r. odnotowana jest kwota 10 zł przekazana złotnikowi, jako zapłata za zrobienie korony do obrazu św. Franciszka ${ }^{45}$. Wielki rozgłos musiało mieć bractwo w XVIII w., ponieważ w archiwaliach spotykamy spisy członów arcybractwa Paska św. Franciszka, zapewne tych, którzy już należeli do bractwa, jak i nowo przyjętych. Spisy pochodzą z lat: 1744, 1745, 1746, 1747, 1748 oraz $1749^{46}$. Dalsze losy arcybractwa Paska św. Franciszka przy kościele franciszkanów w Krośnie nie są znane. Wydaje się jednak, że bractwo działało nadal aż do okresu józefinizmu, wtedy wszystkie bractwa zostały rozwiązane.

W okresie od początku XVII w. do połowy XVIII w. stan liczebny bractw Paska św. Franciszka, działających przy kościołach Braci Mniejszych Konwentualnych, wynosił łącznie 33 stowarzyszenia. W prowincji polskiej istniały

\footnotetext{
Ordinis Minorum ... Provincialis 1598 vel 1609, AFK, [b. sygn.]; Alojzy Karwacki, Inwentarze i streszczenie uporządkowanego Archiwum Konwentu OO. Franciszkanów w Krośnie, AFKr., [b. sygn.], 137.

${ }^{42}$ Methodus duplicis visitationis spiritualis et temporalis totius Provinciae Poloniae cura et vigilantia A.R.P. Adami Goski. 20 Iunii 1612 - 20 lunii 1615, AFK, [b. sygn.]; Karwacki, Inwentarze, 139.

${ }^{43}$ Fr. Felix Franceschinus był generałem w latach 1625-1635.

${ }^{44}$ Odpusty dla Bractwa św. Paska, AFKr, sygn. A 4 pap. 1628. Dokument został wystawiony w Rzymie 4 października 1628 r. Akt jest drukowany z podpisem i pieczęcią generała.

${ }^{45}$ Registra acceptarum et expensarum 1679-1685, AFKr., [b. sygn.].

${ }^{46}$ Fasc. J 1744, 1745; AFKr., [b. sygn.].
} 
23 bractwa w następujących miejscowościach ${ }^{47}$ : Bełchatowie, Chełmnie, Chęcinach, Gnieźnie, Grabowie, Inowrocławiu, Kaliszu, Krakowie, Lelowie, Łagiewnikach, Nieszawie, Nowym Korczynie, Obornikach, Piotrkowie, Poznaniu, Pyzdrach, Radomsku, Radziejowie, Smardzewicach, Starym Sączu, Śremie, Warce i Warszawie. W prowincji ruskiej istniało 10 bractw przy następujących klasztorach: w Gródku Jagiellońskim, Haliczu (św. Stanisław), Kamieńcu Podolskim, Kalwarii Pacławskiej, Krośnie, Krzemieńcu, Lwowie, Przemyślu, Sanoku i Szczebrzeszynie. W prowincji litewskiej istniały 4 bractwa: w Drohiczynie, Wilnie, Oszmianie, Kownie ${ }^{48}$.

\section{ARCYBRACTWO MĘKI PAŃSKIEJ}

Inną, prężnie działającą wspólnotą przy wielu kościołach franciszkanów w XVII i XVIII w. w Polsce było arcybractwo Męki Pańskiej założone w Krakowie. Krakowskie arcybractwo Męki Pańskiej zostało założone przez kanonika kapituły krakowskiej, a późniejszego biskupa Marcina Szyszkowskiego, 9 czerwca 1595 r. przy kościele franciszkanów ${ }^{49}$. Dzięki poparciu i przywilejom papieży Klemensa VIII i Pawła V, krakowskie bractwo Męki Pańskiej zostało podniesione do rangi arcybractwa i otrzymało prawo do afiliowania wszystkich bractw o tej samej nazwie ${ }^{50}$, stąd biskup Marcin Szyszkowski ${ }^{51}$, jako założyciel, miał prawo erygować i agregować nowo powstające bractwa Męki Pańskiej przy innych kościołach franciszkańskich. W 1625 r. ten sam Szyszkowski, już jako biskup krakowski, wzniósł przylegającą do kościoła franciszkanów kaplicę Męki Pańskiej, przy której do dzisiaj istnieje i działa bractwo Męki Pańskiej².

\footnotetext{
${ }^{47}$ Damian Synowiec, „Franciszkanie Polscy 1772-1970”, w Zakony św. Franciszka w Polsce w latach 1772-1970, t. 2, red. Joachim Bar (Warszawa: Akademia Teologii Katolickiej, 1978), 92; Bonawentura Makowski, Brevis Descriptio Conventuum Provinciae Poloniae Ordinis Minorum Conventualium S.P. Francisci, 1762, AFK, [b. sygn.], 173.

${ }^{48}$ Synowiec, „Franciszkanie Polscy 1772-1970”, 92-93; Makowski, Brevis Descriptio, s. 173; Kuczkowski, „Arcybractwo Paska św. Franciszka”, 58.

${ }^{49}$ Acta Archiconfraternitatis Compassionis Jesu Christi et Beatissimae Virginis Mariae pochodzą z omawianego okresu. Rękopis obejmuje lata 1611-1688; znajduje się w AFK, sygn. A-VI-8.

${ }^{50}$ Zob. Antoni Zwiercan, „Bractwo Męki Pańskiej w Krakowie (1595-1795)”, Prawo Kanoniczne 26(1983), 1-2: 83-201.

${ }^{51}$ Marcin II Szyszkowski herbu Ostoja (ur. 1554 w Iłży, zm. 30 IV 1630 w Krakowie) - książę siewierski, biskup łucki, płocki, a później krakowski. Zob. Krzysztof Rafał Prokop, Poczet biskupów krakowskich (Kraków: Wyd. Św. Stanisława BM Archidiecezji Krakowskiej, 1999), 157-160.

${ }^{52}$ Piotr Pruszcz, Kleynoty stołecznego miástá Krakowa, albo koscioty, y co w nich iest widzenia godnego y znácznego, przez Piotra Hiacyntha Prvszcza, krotko opisane, Powtornie záś z pilnośćia
} 
W odniesieniu do postaci biskupa Szyszkowskiego i jego relacji z franciszkanami i bractwem Męki Pańskiej zachodzi bardzo istotny związek. Dotyczy on powodów fundacji w 1595 r. przez ówczesnego kanonika kapituły katedralnej Marcina Szyszkowskiego bractwa Męki Pańskiej właśnie przy krakowskim kościele franciszkanów. Bractwo kierowało się własnymi ustawami, napisanymi w 1607 r. przez bpa Szyszkowskiego ${ }^{53}$. Statuty brackie zostały ogłoszone drukiem pt. Bractwo Compassionis albo Męki Pana Jezusowej i B. P. Mariej w Krakowie u św. Franciszka zatożone (Kraków 1607). Biskup Marcin Szyszkowski wydał ponownie w języku łacińskim ustawy brackie na synodzie krakowskim w 1621 roku pt. Descriptio officiorum Archiconfraternitatis Compassionis Christi, razem z postanowieniami synodu krakowskiego ogłoszonymi drukiem w Rejormationes generales ad clerum et populum dioecesis Cracoviensis pertinentes (Kraków 1621) ${ }^{54}$.

Bractwo miało własne dochody, które pochodziły ze składek członków i zapisów dobrodziejów na rzecz konfraterni. Jego organizacja była podobna do organizacji innych bractw powstających w tym okresie, jednak jedna rzecz go wyróżniała. Związek bractwa $\mathrm{z}$ franciszkanami polegał na tym, że spośród zakonników wybierano prefekta, czyli opiekuna bractwa, przy czym wybór osoby zależał od bractwa, a nie od klasztoru. Prefekt otrzymywał zapłatę za swoje obowiązki. Do jego obowiązków należało: głosić kazania; odprawiać nabożeństwa; słuchać spowiedzi braci; na prośbę braci chodzić do więzienia z Komunią św. dla więźniów. Stąd prefektom stawiano wysokie wymagania intelektualne i zabiegano, aby byli dobrze przygotowani teologicznie. Dlatego niektórzy historycy twierdzą, że głównym powodem ufundowania tzw. Collegium Szyszkovianum ${ }^{55}$ (studium filozoficzno-teologiczne ze szkołą przygotowawczą dla chłopców) w klasztorze franciszkanów przez biskupa Szyszkowskiego

przeyźrzáne, y do druku z additámentem nowych Kośćiołow y Relikwii S. podane, z pozwoleniem Zwierzchnośći Duchowney (Kraków: W Drukarni Akademickiey, 1745), 22.

${ }^{53}$ Kantak, Franciszkanie polscy, 292.

${ }^{54}$ Rejormationes generales ad clerum et populum dioecesis Cracoviensis pertinentes (Cracoviae: in Officina Andrea Petricovij 1621), 82-147.

${ }^{55}$ Kolegium krakowskie franciszkanów otrzymało nazwę Szyszkovianum od krakowskiego biskupa Marcina Szyszkowskiego, który ufundował i utrzymywał kolegium, a przez to przyczynił się w znaczny sposób do jego rozwoju. Uroczyste otwarcie działalności kolegium miało miejsce 7 maja 1622 r. i zostało założone dekretem generała zakonu franciszkanów $z$ dwoma lektorami przewodnimi i bakałarzem, którzy mieli być mianowani tylko przez generała zakonu. Studenci byli zobowiazani przez trzy lata studiować święta teologię w programie z filozofia lub metafizyka w ujęciu skotystycznym. Kolegium rozwinęło się bardzo, gdy otrzymało rangę jednej z ośmiu najwyższych instytucji naukowych w całym zakonie franciszkańskim potwierdzoną dekretem generała oraz przez Konstytucje Urbańskie w 1628 r. Karwacki, Materiaty do historii, t. 3, 379; Kantak, Franciszkanie polscy, 301. 
była chęć zabezpieczenia odpowiednio przygotowanych teologicznie franciszkanów do prowadzenia bractwa. Do końca jednak nie można się z tą tezą zgodzić. Owszem Szyszkowski, fundując kolegium, postawił franciszkanom warunek, że każdorazowy regens kolegium będzie jednocześnie prefektem arcybractwa. Początkowo ten warunek był wypełniany zgodnie z życzeniem fundatora, np. wiemy, że Adrian Bratkowicz ${ }^{56}$, po zakończeniu posługi jako prowincjał, w $1629 \mathrm{r}$. został prefektem Bractwa Męki Pańskiej i równocześnie piastował urząd regensa. Dzięki tej posłudze zasłużony franciszkanin Bratkowicz wydał drukiem kazania wygłoszone do Bractwa Męki Pańskiej pt. Rozmowa duchowna y nabozne uwazanie o siedmi stowa Pana Jezusowych na Krzyżu wyrzeczonych. Gwoli Arcybractwu Męki Panskiey od s. p. J. M. X. Mar. Szyszkowskiego, Bisk. Krak. u Oycow Franciszkanow zatożonemu: do druku podana przez W. O. Adriana Bratkowica Pis. S. Dok. Regenta Krak. Braci mnieyszych, Konventuatow Franciszka S. nazwanych Zakonnika, Praefekta Arcybractwa Męki Panskiey. w Krak. w Druk. Fr. Cezarego, 1633 (Kraków 1633) ${ }^{57}$. Biskup Szyszkowski w akcie fundacyjnym ponadto nałożył studentom obowiązek głoszenia kazań w kaplicy bractwa ${ }^{58}$.

Nabożeństwa bractwa skupiały liczną rzeszę wiernych i dawały szerokie pole do działalności kaznodziejskiej i duszpasterskiej franciszkanów. Odbywały się one nie tylko w piątki, ale także w inne dni w okresie Wielkiego Postu. Szczególnym dniem dla bractwa był każdy piątek w Wielkim Poście. W tych dniach gromadzono się na uroczystej Mszy św. o Męce Pańskiej, w kaplicy pod tym samym wezwaniem. Nabożeństwo pasyjne rozpoczynało się nieszporami, rozważano wówczas Chrystusowe cierpienia i współcierpienia Jego Matki. Potem śpiewano litanię, podczas której bracia w czarnych kapach leżeli krzyżem na posadzce. Dwóch z nich niskim głosem powtarzało co jakiś czas słowa po łacinie: „Memento homo mori”, zaraz potem te same słowa po polsku: „Pamiętaj człowiecze na śmierć”. W czasie nabożeństwa kaznodzieja wygłaszał kazanie o męce Chrystusa. Po nabożeństwie następowała procesja z Najświętszym Sakramentem, podczas której śpiewano „Stabat mater”. Bracia szli w tzw. procesji jerozolimskiej parami, w czarnych kapach z kapturami na głowie oraz z symbolicznymi narzędziami męki Jezusa Chrystusa, słuchając

${ }^{56}$ Adrian Bratkowicz z Iłży należał do najbardziej zasłużonych i najwybitniejszych teologów franciszkańskich początku XVII w. Przez wiele lat wykładał w studium zakonnym w Krakowie filozofię i teologię. Owocem tej pracy było kilka rozpraw teologicznych. Julian Bartosiewicz, „Księga protokołów franciszkańskich prowincji ruskiej 1625-1650”, Studia Historyczne i Literackie 3(1881):115; Kantak, Franciszkanie polscy, 252-254.

${ }^{57}$ Est, XIII, 322.

${ }^{58}$ Kantak, Franciszkanie polscy, 294. 
pasji granej przez orkiestrę lub organistę. Na znak umartwienia i jednoczenia się z cierpieniami Chrystusa bracia szli boso ${ }^{59}$.

W ciągu roku bractwo Męki Pańskiej obchodziło trzy uroczystości odpustowe. Były to uroczystości Znalezienia Krzyża św. (3 maja), Podwyższenie Krzyża św. (14 września) i święto Stygmatów św. Franciszka z Asyżu (17 września). Wszystkie uroczystości odpustowe były obchodzone w ozdobionej kaplicy Męki Pańskiej z podwójnymi nieszporami w przeddzień i w samą uroczystość, z procesjami jerozolimskimi, egzortami i kazaniami. Główna Msza św. zwana sumą była z wystawianiem Najświętszego Sakramentu, podobnie nieszpory. Uroczystości często uświetniała orkiestra ${ }^{60}$.

$\mathrm{Na}$ uwagę zasługuje również działalność społeczno-religijna bractwa wśród więźniów. Bracia opiekowali się więźniami, co kwartał ich odwiedzali, zanosili im jałmużnę, zaopatrywali w bieliznę, nosili obiad, spłacali długi. Sprawowali również opiekę duchową nad nimi zachęcając ich do poprawy życia i do skruchy. Gdy więźniowie pragnęli się wyspowiadać i przyjąć Komunię św. o pomoc proszono franciszkanów, którzy szczególnie w Wielkim Tygodniu zwykli byli tę praktykę odbywać. Nie wiadomo, czy wszystkie bractwa agregowane do arcybractwa krakowskiego, miały również przywilej uwalniania więźniów podczas Wielkiego Tygodnia. Arcybractwo krakowskie chlubiło się z tego przywileju, nadanego przez króla Władysława IV ${ }^{61}$.

Bractwo kierowało się własnymi ustawami, napisanymi w 1607 r. przez bpa Szyszkowskiego. Jego organizacja była podobna do organizacji innych bractw powstających w tym okresie. Bractwo miało własne dochody, które pochodziły ze składek członków i zapisów dobrodziejów na rzecz konfraterni ${ }^{62}$. Związek bractwa z franciszkanami polegał na tym, że spośród zakonników wybierano prefekta, czyli opiekuna bractwa, przy czym wybór osoby zależał od bractwa, a nie od klasztoru. Prefekt otrzymywał zapłatę za swoje obowiązki. Do jego obowiązków należało: głosić kazania; odprawiać nabożeństwa; słuchać spowiedzi braci; na prośbę braci chodzić do więzienia z Komunią św. dla więźniów ${ }^{63}$. Bractwo zdobywało coraz to nowych członków, wśród których nie brakowało patrycjatu miejskiego, inteligencji, a także szlachty.

Najbardziej popularną formą działalności kultowej bractwa Męki Pańskiej stały się procesje. $\mathrm{Na}$ żadnych innych nabożeństwach nie występowali tak

\footnotetext{
${ }^{59}$ Karwacki, Materiaty, t. 7, 319; Kantak, Franciszkanie polscy, 291-294.

${ }^{60}$ Zwiercan, „Bractwo Męki Pańskiej”, 148.

${ }^{61}$ Karwacki. Materiaty, t 7, 319; Kantak, Franciszkanie polscy, 293; Zwiercan, „Bractwo Męki Pańskiej”, 113.

${ }^{62}$ Fasc. L 1785 VII, AFKr., [b. sygn.].

${ }^{63}$ Kantak, Franciszkanie polscy, 292.
} 
licznie bracia jak na procesjach. W Krakowie bractwo Męki Pańskiej miało zwyczaj urządzania procesji do siedmiu kościołów Krakowa w Wielki Piątek, w celu odwiedzania tzw. grobów Pańskich. Procesje wielkopiątkowe, połączone z nawiedzaniem grobów, stały się misteriami przedstawiającymi drogę Chrystusa z żołnierzami. Później procesja do siedmiu kościołów w Wielki Piątek przekształciła się w przedstawienie Drogi Krzyżowej ${ }^{64}$. W poniedziałek wielkanocny bractwo urządzało procesję na Zwierzyniec do klasztoru norbertanek zwaną procesją emausową ${ }^{65}$. Również krakowskie bractwo Męki Pańskiej wytworzyło pobożny zwyczaj urządzania corocznie procesji do następujących kościołów krakowskich: „na Piasek”, czyli do kościoła karmelitów, do kościoła Panny Maryi w Rynku i do kościoła dominikanów do grobu św. Jacka. Bractwo zawsze licznie i chętnie brało udział w procesji na Boże Ciało. W Krakowie procesja Bożego Ciała gromadziła liczne bractwa, w tym 4 bractwa działające przy kościele franciszkanów: św. Jana Chrzciciela, Męki Pańskiej, Paska św. Franciszka i św. Antoniego.

Bractwa wzajemnie na siebie oddziaływały i ze sobą rywalizowały. Przykładowo w rywalizacji między bractwami krakowskimi dochodziło do sporów o pierwszeństwo w publicznych wystąpieniach na procesjach i na pogrzebach. W 1622 roku po raz pierwszy wystąpiło publicznie bractwo św. Anny i na procesji Bożego Ciała „przeniosło przodkowanie w procesjej”. Bractwo Męki Pańskiej nie chciało ustąpić bractwu św. Anny, dopiero duchowni przywrócili porządek. Bractwo św. Anny postarało się o dekret oficjała krakowskiego gwarantujący mu miejsce między bractwem włoskim św. Jana Chrzciciela a bractwem Męki Pańskiej ${ }^{66}$.

Dynamiczny rozwój bractw Męki Pańskiej wystąpił za życia fundatora, biskupa Szyszkowskiego. Przegląd chronologiczny powstawania bractw Męki Pańskiej w różnych miejscowościach Polski i na Śląsku pozwala ustalić, że okresem wielkiego rozwoju była pierwsza połowa XVII wieku. W tym czasie w niektórych latach nawet kilka bractw Męki Pańskiej powstawało w Polsce. W 1608 roku, dnia 12 maja, zostało założone bractwo Męki Pańskiej we Lwowie ${ }^{67}$, a 6 grudnia tego roku w Nowym Sączu $(1608)^{68}$. W 1626 roku powstało sześć bractw Męki Pańskiej: 11 marca w Lublinie (1626) ${ }^{69}, 17$ lipca w Pyzdrach

\footnotetext{
${ }^{64}$ Zwiercan, „Bractwo Męki Pańskiej”, 151-152.

${ }^{65}$ Tamże, 152-153.

${ }^{66}$ Tamże, 185-186.

${ }^{67}$ Tamże, 176.

${ }^{68}$ Makowski, Thesaurus Provinciae Poloniae, 232-233, 257.

${ }^{69}$ Tamże, 30.
} 
$(1626)^{70}$ i w Śremie $(1626)^{71}$, w październiku w Piotrkowie $(1626)^{72}$, a także w Radziejowie, gdzie jest znana tylko data roczna $(1624)^{73}$. W innych klasztorach bractwo powstało w podobnym okresie: Gniezno (1596) ${ }^{74}$, Grabów $(1600)^{75}$, Kalisz $(1614)^{76}$, Opole (przed 1615) ${ }^{77}$, Warka $(1635)^{78}$, Nieszawa, Radomsko $(1616)^{79}$, gdzie na dokumencie erekcyjnym bractwa Męki Pańskiej w Radomsku jest podpisany superintendent arcybractwa Jakub Ostrowski kanonik krakowski. Akt erekcyjny, w większości wypadków, wystawiał sam założyciel biskup Marcin Szyszkowski. Na mocy bulli Pawła V to samo prawo posiadało arcybractwo Męki Pańskiej w Krakowie. Na zebraniu brackim wystawiano dokument erekcyjny ${ }^{80}$.

Największe zagęszczenie bractw Męki Pańskiej wystąpiło w etnicznie rdzennej Polsce. Ilustrują to bractwa założone przy klasztorach franciszkańskich. W prowincji polskiej było 17 bractw Męki Pańskiej, natomiast na kresach wschodnich, w prowincji ruskiej, powstało $7 \mathrm{i}$ w prowincji litewskiej 3 . Bractwa powstawały w miastach i miasteczkach. Główną rolą w organizowaniu bractw po Soborze Trydenckim odegrali mieszczanie. Mieszkańcy miast wykazali wiele inicjatywy i brali czynny udział w działalności kultowo-społecznej bractw Męki Pańskiej. Na wschodnich terenach państwa polskiego element mieszczański poza wielkimi miastami był słabszy i to często niekatolicki. $Z$ tego względu bractwa nie mogły rozwinąć szerszej działalności kultowo-społecznej. Przykładem tego może być Drohiczyn, gdzie bractwo Męki Pańskiej około 1615 roku nie mogło zdobyć się na wspólne nabożeństwa z powodu małej liczby braci ${ }^{81}$.

Były sytuacje, że wprost o założenie bądź agregację starali się świeccy mieszczanie. Dnia 22 listopada 1612 roku w Krośnie biskup Marcin Szyszkowski dokonał agregacji tamtejszego bractwa Męki Pańskiej do arcybractwa w Krakowie

${ }^{70}$ Tamże, 464, 473; Piasecki, Opisanie kościołów i klasztorów księży franciszkanów, 87.

${ }^{71}$ Makowski, Thesaurus Provinciae Poloniae, 483.

${ }^{72}$ Zwiercan, „Bractwo Męki Pańskiej”, 177.

${ }^{73}$ Piasecki, Opisanie kościołów i klasztorów księży franciszkanów, 64.

${ }^{74}$ Gnieźnieńskie bractwo Męki Pańskiej należało do najstarszych w Polsce - założone 1596. Makowski, Thesaurus Provinciae Poloniae, 534.

${ }^{75}$ Tamże, 416-417.

${ }^{76}$ Tamże, 461; Piasecki, Opisanie kościołów i klasztorów księży franciszkanów, 29.

${ }^{77}$ Po okresie protestantyzmu polscy franciszkanie wrócili w 1606 roku do Opola. Prowincjał polski Adam Goski, wizytujący klasztor w Opolu przed 1615 rokiem, przeznaczył dla bractwa Męki Pańskiej sprofanowaną przez protestantów (kaplicę książąt opolskich). Kantak, Franciszkanie polscy, 160; Karwacki, Materiaty, t. 13, 11.

${ }^{78}$ Makowski, Thesaurus Provinciae Poloniae, 13.

${ }^{79}$ Piasecki, Opisanie kościołów i klasztorów księży franciszkanów, 113.

${ }^{80}$ Zwiercan, „Bractwo Męki Pańskiej”, 177.

${ }^{81}$ Karwacki, Materiaty, t. 5, 84; Zwiercan, „Bractwo Męki Pańskiej”, 177-178. 
na prośbę rodzonych braci Jana i Jakuba Łopackich i innych znakomitych mieszczan krośnieńskich. Arcybractwo w Krośnie zostało założone w 1612 r. na wzór krakowskiego i do niego też agregowane ${ }^{82}$. Działając w Krośnie, bractwo odegrało niemałą rolę w szerzeniu kultu Męki Pańskiej. Już w 1618 r. konfraternia mogła się poszczycić własną kaplicą, którą wybudowano wzdłuż prawej nawy kościoła. Zadziwia fakt, że kaplica Męki Pańskiej, bo takie wezwanie otrzymała, została wybudowana w bardzo krótkim czasie. Z ksiąg rachunkowych klasztoru wynika, że budowę rozpoczęto w lecie 1617 r., a zakończono na początku 1618 r. ${ }^{83}$ Również z tych ksiąg wynika, że w kaplicy od razu wybudowano ołtarz i namalowano specjalny obraz do tego ołtarza ${ }^{84}$. Nie powinno nas jednak dziwić tempo budowy i tak szybkie jej zakończenie, gdy weźmiemy pod uwagę popularność bractwa, dzięki której klasztor szybko znalazł wielu dobrodziejów, oferujących swoją pomoc materialną przy budowie ${ }^{85}$. Potwierdzają to zapisy ofiar na kaplicę w księdze dochodów klasztoru ${ }^{86}$.

Niewątpliwie na pochwałę zasługują tutaj franciszkanie, którzy w duchu potrzeb ówczesnego Kościoła potrafili odpowiadać na nowe, często bardzo trudne duszpasterskie wyzwania. Dzięki bractwu Męki Pańskiej w kościołach franciszkańskich zostało wprowadzone nabożeństwo Drogi Krzyżowej. W Krośnie nowe nabożeństwo zostało zapoczątkowane w święto Podwyższenia Krzyża, 14 września 1744 r., przez bernardyna z Dukli Eleazara Kalinowskiego. Na terenach Polski, w tym okresie jedynie bernardyni i reformaci mieli przywilej

\footnotetext{
${ }^{82}$ Dokument fundacji Arcybractwa Męki Pańskiej, AFKr, sygn. A 3 pap. 1626. Kopia poświadczona przez biskupów przemyskich: Achacego Grochowskiego i Antoniego Wacława Betańskiego, co do zgodności z oryginałem.

${ }^{83}$ Registra acceptarum et expensarum 1616-1621, AFKr. [b. sygn.]. Zapisy dotyczące budowy kaplicy: 26 sierpnia 1617 r.: za piwo mularczykom, kiedy kaplice sklepili - 2 gr.; 12 luty 1618 r.: ze skrzynki, która w kaplicy Compassionis viszy - 3 floreny i 15 gr. W kwietniu 1618 r. komisarz generalny Antoni Cervini stwierdził, że kaplica Męki Pańskiej była ukończona i urządzona (Visitatio localis et personalis Conventuus per P. M. Antonium Cervinum Vicarium et comissarium generalem Provinciae O.M.C. incepta AD 1618 die ultima aprilis, AFK, [b. sygn.]). W 1721 r. członkowie bractwa i dobrodzieje ofiarowali 150 zł na remont swojej kaplicy (Registra acceptarum et expensarum 1703-1722, AKFr., [b. sygn.].

${ }^{84}$ Registra acceptarum et expensarum 1616-1621. Dnia 23 listopada 1617 r.: na ptótno na obraz Compassionis - 10 gr.: za farby na tenże obraz - 16 gr.: za ramy do malowania tegoż obrazu - 4 gr.; 11 października 1617 r.: od zrobienia ottarza w kaplicy murarzowi... lub 18 grudnia 1617 r.: za farbę którq się ottarz zmalowat - $10 \mathrm{gr}$.

${ }^{85}$ Registra acceptarum et expensarum 1703-1722, AFKr. [b. sygn.]. W 1721 r. w lipcu bractwo otrzymało ofiarę 50 zł od dobrodzieja Pana Dombrowskiego.

${ }^{86}$ Registra acceptarum et expensarum 1616-1621. Z pomocą materialną przy budowie kaplicy pospieszyli sami członkowie bractwa ofiarując na ten cel w sumie 47 florenów (zapisy z 7 lipca, 14 lipca i 9 października 1617 r.).
} 
inicjowania nabożeństwa ${ }^{87}$. W krótkim czasie stało się słynne wśród wiernych, tłumnie przychodzących w każdy piątek, aby duchowo przeżywać mękę Jezusa.

Chlubna działalność bractwa Męki Pańskiej przy kościele franciszkanów w Krośnie została przerwana wraz ze zmianami politycznymi pod koniec XVIII w. Bractwo podzieliło losy innych bractw, tzn. zostało skasowane z nakazu zaborcy austriackiego. W 1785 r. w kwietniu klasztor przesłał do cyrkułu w Dukli spis majątku bractwa Męki Pańskiej ${ }^{88}$. Spis ten podaje krótką historię bractwa i ostatnie obowiązki: śpiew różańca w każdy piątek w kaplicy Męki Pańskiej, kwartalną Mszę św. żałobną za zmarłych członków bractwa i raz do roku odprawiane nabożeństwo przebłagalne oraz trzy Msze św. w ciągu roku czytane. Bractwo przestało istnieć, a dokumenty zabrano do cyrkułu w Dukli ${ }^{89}$.

W Polsce w całym okresie od końca XVI w. do XVIII w. przy kościołach franciszkańskich powstało i działało 27 bractw Męki Pańskiej. W prowincji polskiej istniało 17 kongregacji prowadzonych przez franciszkanów: w Chełmnie, Grabowie, Gnieźnie, Kaliszu, Krakowie, Lelowie, Lublinie, Nieszawie, Nowym Korczynie, Nowym Sączu, Piotrkowie, Pyzdrach, Radomsku, Radziejowie, Stężycy, Śremie, Warce. W prowincji ruskiej istniało 7 kongregacji: w Gródku Jagiellońskim, Krośnie, Krzemieńcu, Lwowie, Sanoku, Przemyślu, Zamościu, natomiast w prowincji litewskiej istniały tylko 3 kongregacje: w Drohiczynie, Kownie i Wilnie ${ }^{90}$. Biskup Marcin Szyszkowski na synodzie krakowskim zalecił zakładanie bractw Męki Pańskiej w swojej diecezji, szczególnie przy kościołach kolegiackich, parafialnych i zakonnych, które miały więcej kleru i ludu. Powstały bractwa Męki Pańskiej przy kościołach parafialnych: w 1625 roku w Chotowie, Bodzentynie, Bełzie ${ }^{91}$.

${ }^{87}$ Liber Beneficiorum Conventus Crosnensis, in quo continentur privilegia, census ac fundationes illus factus, sub regimine guardianatus P.P Fratris Leonardi Crac., Provicialatus vero A. R. P. Alberti Ghiza S. T. D. Anno D. 1628. Die XII. M. Dec., AFKr., [b. sygn.], [strona przed kartą tytułową]; Karwacki, Inwentarze, 85 (Nabożeństwo Drogi Krzyżowej zostało ustanowione w 1692 r. przez papieża Innocentego XII, który nadał franciszkanom prawo wprowadzania tego nabożeństwa w kościołach).

${ }^{88}$ Prawdopodobnie ostatniej fazie działalności bractwo Męki Pańskiej zostało połączone z bractwem Różańcowym. Wskazuje na to spis dochodów obydwu bractw, gdzie podany jest jeden promotor, jeden zarząd, te same dochody oraz wspólne praktyki modlitewne. (Fasc. L 1785 VII, AFKr., [b. sygn.].

${ }^{89}$ Fasc. L 1785 VII, AFKr. [b.sygn.]; Karwacki, Inwentarze, 94-95.

${ }^{90}$ Synowiec, ,Franciszkanie Polscy 1772-1970”, 91-93.

${ }^{91}$ Zwiercan, „Bractwo Męki Pańskiej”, 175. 


\section{BRACTWO ŚW. ANTONIEGO PADEWSKIEGO}

W drugiej połowie XVII w. przy kościołach franciszkańskich w Polsce rozwinął się kult św. Antoniego Padewskiego. Prawdopodobnie miało to związek z objawieniami świętego w Łagiewnikach k/Łodzi, gdzie w późniejszym okresie franciszkanie rozpowszechnili kult budując kościół z klasztorem i tworząc sanktuarium św. Antoniego z Padwy znane w całym Królestwie Polskim. Chociaż wszystkie gałęzie franciszkańskie szerzyły kult świętego z Lizbony, to jednak dzięki sanktuarium w Łagiewnikach, właśnie franciszkanie konwentualni stali się głównymi propagatorami kultu w całej ówczesnej Polsce. Po sporze z bernardynami w Poznaniu w 1667 r. franciszkanie konwentualni uzyskali pierwszeństwo do propagowania kultu i do bractwa św. Antoniego, które zaczęło się rozpowszechniać ${ }^{92}$. Działalność bractwa w Polsce zapewne nawiązywała do działalności Arcybractwa św. Antoniego przy bazylice Świętego w Padwie, gdzie znajduje się grób świętego. Początki tamtego bractwa sięgają XIII wieku. Tradycja przyjmuje, że bractwo powstało kilka lat po śmierci i kanonizacji św. Antoniego, które miały miejsce odpowiednio w 1231 i 1232 r., ale pierwszy dokument świadczący o jego obecności pochodzi z 1298 roku $^{93}$. Pierwszy statut, który mówił o obowiązkach braci, pochodzi z 1334 r. Na ich czele stał opiekun, tzw. strażnik, któremu pomagali czterej tzw. gastaldi, po jednym na każdej z czterech dzielnic miasta. Bractwo, które powstało pod patronatem Zakonu Braci Mniejszych Konwentualnych, miało charakter stowarzyszenia złożonego z osób świeckich obojga płci i duchownych zaangażowanych $\mathrm{w}$ formację religijną swoich członków, praktykowanie ewangelicznej miłości i szerzenie pobożności antoniańskiej. Statut zabraniał przyjmowania żołnierzy, lichwiarzy, pijaków, bluźnierców, cudzołożników, morderców, hazardzistów i oszustów, ponieważ członkowie musieli prowadzić nieskazitelne życie. Wśród nakazów dla sióstr i braci był obowiązek wspólnotowego uczestniczenia we Mszy świętej celowo odprawianej w każdą pierwszą niedzielę miesiąca. Na koniec świętego obrzędu wszystkim rozdawano tzw. focaccia (o czym świadczy pierwszy z fresków, który można znaleźć przy wejściu do historycznej siedziby arcybractwa przy bazylice w Padwie, gdzie strażnik rozdaje chleb pod drzwiami kościoła). Tradycja ta w następnych stuleciach stała się tzw. Chlebem Św. Antoniego i jest do dzisiaj kontynuowana. Na zakończenie Mszy św. bractwa w pierwszą niedzielę

\footnotetext{
${ }^{92}$ Kantak, Franciszkanie polscy, 295-296.

${ }^{93}$ Pierwszy dokument potwierdzający istnienie „fratalee Sancti Antonij” sięga 1298 roku (Archiwum Państwowe w Padwie, sygn. B. 74, 124).
} 
miesiąca, błogosławiony jest i rozdawany pielgrzymom Chleb św. Antoniego, a zebrane $\mathrm{w}$ ten sposób dobrowolne ofiary są wykorzystywane w dziełach charytatywnych. Współbracia angażowali się także w pomoc ubogim, z miłością odwiedzając i pomagając chorym, brali udział w pogrzebach oraz $\mathrm{w}$ modlitwach za członków i dobroczyńców bractwa. Głównym świętem bractwa była tzw. Festa della Nogara (święto drzewa orzechowego), obchodzone w niedzielę po święcie św. Antoniego. Z tej okazji członkowie bractwa udawali się w procesji z katedry w Padwie do bazyliki św. Antoniego, aby ofiarować świecę Świętemu. Przez lata działalności bractwa jego członkowie rozwinęli dwie ważne formy pobożności: praktykę tzw. trediciny (modlitwy trzynastu dni - wtorków) oraz wtorki poświęcone św. Antoniemu ${ }^{94}$.

Chronologicznie najstarszym bractwem św. Antoniego w Polsce wydaje się być wspólnota założona w Krakowie przez słynnego kaznodzieję królewskiego i prowincjała franciszkanów w Polsce w latach 1663-1666 Waleriana Gutowskiego $^{95}$, który już 8 stycznia 1664 r. uzyskał brewe od papieża Aleksandra VII pozwalające na założenie bractwa w najstarszym kościele franciszkanów w Polsce. W Krakowie, gdzie wcześniej bractwo Męki Pańskiej cieszyło się wielkim uznaniem, po najeździe szwedzkim niezwykle popularny stał się kult św. Antoniego. W 1664 roku czcicieli tego Świętego zorganizował w odrębne bractwo kaznodzieja Walerian Gutowski. Nabożeństwa na część „Cudotwórcy” odbywały się z tłumnym udziałem ludu ${ }^{96}$. Oficjalnie bractwo św. Antoniego swoją działalność rozpoczęło 1 sierpnia 1664, wkrótce zostało ono agregowane do arcybractwa św. Antoniego z Padwy przy rzymskiej bazylice XII Apostołów. Historyk franciszkański Bonawentura Makowski (żyjący

${ }^{94}$ Antonio Sartori, L'Arciconfraternita del Santo (Padova: Tip. della Provincia Patavina di S. Antonio dei Frati Minori Conventuali, 1955).

${ }^{95}$ Gutowski Walerian Wojciech (ur. 1629, zm. 1693) pisarz, wybitny teolog i kaznodzieja, gwardian krakowski, wizytator, prowincjał polski. Studiował w Rzymie, gdzie uzyskał doktorat z nauk wyzwolonych i Pisma Świętego. W 1658 r. był regensem studium w Krakowie, w latach 1663-1666 był prowincjałem polskiej prowincji franciszkanów, następnie piastował urząd gwardiana krakowskiego. Wygłosił kazanie na sejmie koronacyjnym króla Michała Wiśniowieckiego w 1669 r. (Wielki Franciszek święty w Maluczkości swojej na kazaniu przy obecności Michała monarchy polskiego, [Kraków 1669]). Zarządzał prowincją polską jako jej komisarz do 1671 r., potem sprawował obowiązki gwardiana i na zmianę kustosza w Krakowie. Zmarł 22 IX 1693 roku i został pogrzebany w kościele franciszkańskim w Krakowie. Estr XVII 477-478; Edward Ozorowski, „Gutowski Walerian Wojciech”, w Stownik Polskich Pisarzy Franciszkańskich, red. Hieronim Wyczawski (Warszawa: Archiwum Prowincji OO. Bernardynów, 1981), 168-169; Kantak, Franciszkanie polscy, 304-308; Ryszard Wróbel, ,Dorobek kaznodziejski franciszkanów (Braci Mniejszych Konwentualnych) w Polsce w XVII i XVIII w.”, w Franciszkanie konwentualni i klaryski w Wielkopolsce od XIII do XIX wieku (Gniezno: Muzeum Początków Państwa Polskiego, 2006), 55-56.

${ }^{96}$ Liber Confraternitatis S. Antoni, AFK, sygn. A IV 5, 2. 
pod koniec XVIII w.) w swoim dziele wspomina pod rokiem 1664 wyżej wymienione brewe: „Anno 1664 obtentum est Breve Aplicum Alexandri PP. VII datum Romae die 8 Januarii pro erigenda Confraternitate S. Antonii Paduani in Ecclesia Nostra Cracoviensis, admissa per Loci Ordinarium die 11 Junii A. 1665. Cujus transumptum authenticum pictura exornatum habetur in Archivio Conventus",97.

Bractwo było „bardzo pożądane w całym mieście” i cieszyło się dużą frekwencją wiernych. Miało charakter kultowo-ascetyczny i prowadziło żywotną działalność charytatywną. Uroczystością patronalną konfraterni było święto św. Antoniego, do której członkowie konfraterni przygotowywali się poprzez nowennę połączoną z postem ${ }^{98}$. Członkowie krakowskiej konfraterni byli zobowiązani do odmawiania własnych modlitw każdego dnia oraz do comiesięcznej Komunii św. Z tego okresu zachowało się oficjum bractwa św. Antoniego z Krakowa z 1673 r.: „Officium albo godzinki bractwa św. Antoniego z Padwy. Kraków 1673",99.

Jedną z istotnych form działalności krakowskiego bractwa św. Antoniego była organizacja procesji i udział w nich. Często nabożeństwa i procesje urządzano razem z innymi bractwami. W 1684 roku w Krakowie w uroczystość św. Wojciecha, obchodzoną przez bractwo św. Antoniego, członkowie bractwa Męki Pańskiej brali udział razem z bractwem św. Antoniego w procesji i nabożeństwach, a także przy wspólnym stole przed ołtarzem św. Antoniego wystawili księgi do zapisywania nowych członków obydwu bractw. Znowu w dwa lata później w 1686 r. bractwo św. Antoniego ustąpiło arcybractwu Męki Pańskiej ze swej uroczystości św. Macieja z racji przypadającego nabożeństwa pasyjnego w niedzielę zapustną ${ }^{100}$.

Do obowiązków bractwa krakowskiego należała nowenna ku czci św. Antoniego z postem i spowiedzią, o czym informuje księga bractwa, a także upowszechnianie kultu Świętego z Padwy. Dzięki bractwom, które w tym okresie zaczęły licznie powstawać przy franciszkańskich klasztorach w Polsce, na Rusi i Litwie rozpowszechniono słynną antyfonę "Si quaeris" oraz inne pieśni ku czci św. Antoniego, które zostały już wcześniej upowszechnione przez

\footnotetext{
${ }^{97}$ Makowski, Thesaurus Provinciae Poloniae, 159.

${ }^{98}$ Liber Confraternitatis S. Antoni, AFK, 1-2; Andrzej Bruździński, „Bractwa religijne w siedemnastowiecznym Krakowie”, w Historia świadectwem czasów. Księdzu profesorowi Markowi Tomaszowi Zahajkiewiczowi, red. Włodzimierz Bielak, Stanisław Tylus (Lublin: Towarzystwo Naukowe KUL, 2006), 103-147.

${ }^{99}$ Estr. XXIII, 279.

${ }^{100}$ Zwiercan, „Bractwo Męki Pańskiej”, 184.
} 
bractwo Paska św. Franciszka ${ }^{101}$. Zapewne z tego okresu pochodzi pieśń: „Witaj Antoni, mieysca Łagiewskiego, Cudo, patronie królestwa polskiego", która rozpowszechniła się po całym Królestwie dzięki franciszkanom łagiewnickim, gdzie założone sanktuarium w szybkim czasie rozwinęło się i szerzyło kult św. Antoniego. Owocem tego kultu były liczne nowe konwenty franciszkańskie pod wezwaniem św. Antoniego w Polsce (Poznań - po 1639, Łagiewniki - po 1678), na Rusi (Lwów - 1645), na Litwie (Mińsk - 1676, Prozoroki - 1677, Nowogródek - 1714). Nie brakowało licznych kazań na cześć św. Antoniego, które publikowali znani kaznodzieje franciszkańscy (Walerian Gutowski, Ludwik Miastkowski $^{102}$, Ludwik Chybiński ${ }^{103}$, Ludwik Zaykiewicz (Zajkiewicz) ${ }^{104}$ ) oraz materiałów franciszkańskich, które służyły bractwom podczas nabożeństw (modlitewniki, oficja, nowenny) ${ }^{105}$. Interesujące w tej tematyce może być dzieło wydane po 1664 r. w drukarni akademickiej w Zamościu, być może opracowane przez franciszkanina na potrzeby bractwa św. Antoniego działającego przy jakimś kościele franciszkanów lub generalnie na potrzeby całej ruskiej prowincji franciszkanów. Dzieło nosi tytuł: „Lilia Z Cnot Swiętych Zgromádzeniá Bráctwá Antoniego S. Zebrana A W Utrápieniu Wiernym Chrystusowym ná Poćiechę Podana”. Z Dokładem świeżo przydánym według Regestru Połozonego. Z Pozwoleniem Stárszych. w Zamosciu. w Drukárni Akádemickiey. B. r. (po 1664) ${ }^{106}$

Jednoznacznie można przyjąć, że inspiracją do zakładania bractw przy kościołach franciszkańskich w Polsce był rosnący kult św. Antoniego Padewskiego. Chęć pozyskania prawa do zakładania bractw przy kościołach

${ }^{101}$ Antyfona Si Quearis rozpowszechniana była przez modlitewniki arcybractwa Paska św. Franciszka, zob. Liricius, Bractwo Chordy, cyt. za: Kantak, Franciszkanie polscy, 290.

${ }^{102}$ W 1695 r. opublikował swoje kazanie Miastkowski Ludwik (zm. 1707), franciszkanin z prowincji litewskiej wygłoszone ku czci św. Antoniego Padewskiego w kościele klasztornym w Stawiskach na uroczystość odpustową tego świętego w dniu 13 czerwca 1695 r., pt. Wrzechmocność Boska ręka św. Antoniego Padewskiego cudowne po świecie dzieła wystawiająca z dawna wstawiona Teraz znowu w nowofundowanym kościele stawiskim Oyców Franciszkanów [...] przy uroczystosci tegoż Świętego Thaumaturga ogłoszona [...], (b.m.w. 1695), zob. Estr XXII 330; Joachim Bar, „Miastkowski Ludwik", w Stownik Polskich Pisarzy Franciszkańskich, 313.

${ }^{103}$ Chybiński Ludwik (ur. 1701, zm. 1748), należał do licznej grupy XVIII-wiecznych historyków franciszkańskich, ogłosił drukiem: Hymny pobożne o św. Antonim (Warszawa 1734), Estr XIV 237, Kantak, Franciszkanie polscy, 413; W. Murawiec, „Chybiński Ludwik”, w Stownik Polskich Pisarzy Franciszkańskich, 87.

${ }^{104}$ Zaykiewicz (Zajkiewicz) Ludwik (zm. 1757), hagiograf, prowincjał ruski. Należał do ruskiej prowincji franciszkanów, której patronem był św. Antoni Padewski, być może dlatego napisał i opublikował jego żywot. Estr XXXIV 91, 461; Kantak, Franciszkanie polscy, 389-390, 400; Joachim Bar, „Zaykiewicz Ludwik”, w Stownik Polskich Pisarzy Franciszkańskich, 548.

${ }^{105}$ Kantak, Franciszkanie polscy, 295.

${ }^{106}$ Estr XXIV, 3-4. 
doprowadziła do zatargu pomiędzy franciszkanami a bernardynami, który został rozstrzygnięty w Poznaniu w $1667 \mathrm{r}$. Minoryci otrzymali wtedy prawo do bractwa św. Antoniego i do zakładania wspólnot przy kościołach zakonnych i diecezjalnych ${ }^{107}$. Bractwa, które w tym czasie powstały w Polsce: Kraków (1664), Warszawa (1664), Radziejów ${ }^{108}$, Pyzdry $(1666)^{109}$, Kalisz (1664), ${ }^{110}$ Gniezno (1673) ${ }^{111}$, Grabów, Stary Sącz ${ }^{112}$, Stężyca, Nieszawa, Smardzewice.

Głównym przejawem działalności bractwa było szerzenie kultu św. Antoniego, praktykowanie nabożeństwa do św. Antoniego, własne uświęcanie, modlitwa w intencji wszystkich potrzebujących pomocy, chorych i cierpiących, a także prowadzenie działalności charytatywnej. Do zadań związanych z działalnością Bractwa należało również: składanie Trójcy Przenajświętszej dziękczynienia za św. Antoniego z Padwy, za jego heroiczne cnoty i przywileje, za jego przedziwną potęgę wstawiennictwa przed Bogiem, za chwałę, do jakiej jest on wynoszony tak w niebie, jak i na ziemi; wypraszanie u Wielkiego Cudotwórcy jego opieki i wstawiennictwa przed Bogiem w różnorodnych potrzebach duszy i ciała dla siebie i wszystkich, włączanie się członków Bractwa w modlitwy wspólnotowe, za braci i siostry z zakonu franciszkańskiego; angażowanie się $\mathrm{w}$ pracę o charakterze charytatywnym, naśladując dzieło samego Świętego dzielenia się chlebem i innymi dobrami z ubogimi i potrzebującymi, a także dzielenia się skarbem cnót ewangelicznych: wiary, nadziei i miłości, poprzez różne formy ewangelizacji ${ }^{113}$.

W Warszawie, w której franciszkanie osiedlili się w 1645 roku, nie powstało bractwo Męki Pańskiej, tylko dwa bardzo popularne bractwa ku czci św. Franciszka (1650 rok) i św. Antoniego (1664 rok) ${ }^{114}$. Warszawskie bractwo św. Antoniego stało się jednym z najbardziej prężnie działających bractw w Polsce. Założone przy warszawskim kościele franciszkanów ze słynącym łaskami cudownym obrazem św. Antoniego, namalowanym przez Mateusza Bertowicza w 1664 roku, miało zajmować się propagowaniem kultu Świętego z Padwy. Bractwo to - zgodnie z dekretem papieża Aleksandra VII - zostało

\footnotetext{
${ }^{107}$ Kamil Kantak, Bernardyni polscy, t. 2 (Lwów: Prowincja Polska OO. Bernardynów, 1933), 258.

${ }^{108}$ Piasecki, Opisanie kościołów i klasztorów księży franciszkanów, 64.

${ }^{109}$ Makowski, Thesaurus Provinciae Poloniae, 464; Piasecki, Opisanie kościołów i klasztorów księży franciszkanów, 87.

${ }^{110}$ Tamże, 30.

${ }^{111}$ Makowski, Thesaurus Provinciae Poloniae, 534.

${ }^{112}$ Lelito, Historia klasztoru, 99-100.

${ }^{113}$ Statut Bractwa Świętego Antoniego z Padwy przy kościele Stygmatów św. Franciszka, Sanktuarium św. Antoniego i klasztorze Zakonu Braci Mniejszych Konwentualnych w Warszawie, Warszawa 2010 (http://www.warszawa.franciszkanie-warszawa.pl/duszpasterstwo/wspolnoty/bractwo-sw-antoniego/)

${ }^{114}$ Zwiercan, „Bractwo Męki Pańskiej”, 179.
} 
założone w dniu 18 stycznia 1664 roku. Dekret papieża Aleksandra VII z roku 1664, nadający odpusty Bractwu św. Antoniego w kościele Ojców Franciszkanów w Warszawie, brzmi następująco: „Papież Aleksander VII na wieczną rzeczy pamiątkę. Otóż przyjęliśmy do wiadomości, że w kościele klasztornym Braci Mniejszych Konwentualnych Zakonu św. Ojca Franciszka z Asyżu, znajdującego się w mieście Warszawa, istnieje pobożne i czcigodne Bractwo św. Antoniego z Padwy, kanonicznie założone i zatwierdzone, do którego należą wierni mężczyźni i kobiety bez ograniczeń co do pochodzenia, czy dziedziczonego stanu, które powszechnie prowadzi bardzo liczne dzieła kultu i miłosierdzia. My, Papież, dla powiększenia tego dobra i jego codziennego wzrostu, mocą i powagą miłosiernego i wszechmocnego Boga oraz władzą świętych Piotra i Pawła Apostołów, wszystkim wstępującym obojga płci do tego Bractwa, w dniu przyjęcia, jeśli tylko przystąpią do Sakramentu Pojednania i Przyjmą Komunię św., udzielam odpustu zupełnego. A także w godzinę śmierci, jeśli oczywiście przystąpią do Sakramentów św. Jeżeli czasem nie mogliby tego uczynić, przynajmniej skruszeni w duchu niech wzywają imienia Jezusa i w myśli Go przywołują. Chcemy także, aby wszystkie inne odpusty, nadane braciom i siostrom tego Bractwa, czy to wieczyste, czy czasowe, trwały nadal. Jeżeli więc wspomniane Bractwo byłoby przyłączone do jakiejś archikonfraterni, albo w przyszłości odłączone, albo z jakiejś przyczyny dołączone, albo przekształcone, albo jakimś pismem skasowane, to tym samym nadane odpusty zostają skasowane. Dano u Matki Bożej Większej pod Pieczęcią Rybaka, dnia 18 stycznia 1664 roku, pontyfikatu naszego roku dziewiątego"115.

Papież Aleksander VII przez brewe nadał konfraterni warszawskiej cztery odpusty: w dzień wstąpienia do bractwa, w dzień nowego roku, we wtorek po Wielkanocy i w dzień Wniebowstąpienia Pańskiego, w dzień Wszystkich Świętych, które obchodziło się z wystawieniem Najświętszego Sakramentu przed ołtarzem św. Antoniego. W 1739 bractwo otrzymało specjalny przywilej od papieża odprawiania wotywy o św. Antonim w każdy wtorek oprócz Adwentu i Wielkiego Postu zakończonej wystawieniem Najświętszego Sakramentu w puszce, zaś w dziewięć wtorków nowenny przed uroczystością św. Antoniego wystawienia dokonywano w monstrancji, a Msza św. była sprawowana z kazaniem i procesją. Uroczystość św. Antoniego była obchodzona bardzo wystawnie ${ }^{116}$.

Bractwo św. Antoniego z Padwy było wspólnotą modlitewno-apostolską, której zadaniem była troska o zbawienie wszystkich ludzi oraz życie zgodne z nauczaniem św. Antoniego z Padwy. Motywacją do modlitwy dla członków

\footnotetext{
${ }^{115}$ Piasecki, Opisanie kościołów i klasztorów księży franciszkanów, 214.

116 Tamże, 214.
} 
bractwa było upraszanie św. Antoniego - Cudotwórcy Bożego wstawiennictwa przed Bogiem w potrzebach całego świata. Szczególnym akcentem aktywności bractwa była pomoc duchowa i materialna dla ubogich, zagubionych, samotnych, chorych, bezradnych, skrzywdzonych, potrzebujących wsparcia i poszukujących drogi do Boga ${ }^{117}$.

Do bractwa mógł wstąpić każdy, kto pragnął służyć Bogu i drugiemu człowiekowi poprzez modlitwę, post, jałmużnę i inne dobre uczynki na wzór św. Antoniego oraz zobowiązał się wypełniać wszystkie obowiązki przypisane bractwu. Uroczyste przyjęcie do bractwa odbywało się podczas Mszy Świętej sprawowanej w kaplicy lub przy ołtarzu św. Antoniego. Obowiązki związane z przyjęciem i przynależnością do Bractwa były następujące: przystąpienie do spowiedzi i przyjęcie Komunii Św. w dniu przyjęcia do Bractwa, w uroczystość św. Antoniego (13 czerwca), w Nowy Rok, w pierwszy wtorek po Wielkanocy, w uroczystość Wszystkich Świętych; celebrowanie wtorków jako dni poświęconych oddawaniu czci św. Antoniemu poprzez uczestnictwo we Mszy św. i nabożeństwie antoniańskim, odmawianie modlitw (3 Ojcze nasz, 3 Zdrowaś Maryjo, 3 Chwała Ojcu, 1 Wierzę w Boga) i responsorium „Si quaeris", uczestnictwo w nowennie ku czci św. Antoniego, spełnianie dzieł miłosierdzia chrześcijańskiego. Przywileje, związane z przyjęciem do bractwa, były następujące: odpust zupełny w dniu przyjęcia do bractwa, w uroczystość Św. Antoniego z Padwy (13 czerwca), w godzinę śmierci lub odpust cząstkowy pod zwykłymi warunkami wymieniony w brewe papieża Aleksandra VII. Fundusze bractwa pochodziły z dobrowolnych składek bractwa oraz darowizn, ofiar i zapisów dobrodziejów i były przeznaczane na ożywianie kultu św. Antoniego poprzez różne formy promocji i ewangelizacji, na pomoc dla potrzebujących i najuboższych $\mathrm{w}$ ramach działalności charytatywnej, na koszty spotkań formacyjnych oraz na bieżące wydatki bractwa.

W prowincjach franciszkanów polskich do czasu rozbiorów Polski istniały łącznie 24 bractwa św. Antoniego. W prowincji polskiej było 21 bractw św. Antoniego: w Nieszawie, Radziejowie, Bełchatowie, Poznaniu, Kaliszu, Krakowie, Pyzdrach, Śremie, Piotrkowie, Obornikach, Gnieźnie, Grabowie, Lelowie, Chełmnie, Inowrocławiu, Warszawie, Smardzewicach, Stężycy, Warce, Łagiewnikach, Starym Sączu; w prowincji ruskiej, która była pod wezwaniem św. Antoniego, istniała do rozbiorów tylko jedna kongregacja

${ }^{117}$ Statut Bractwa Świętego Antoniego z Padwy przy kościele Stygmatów św. Franciszka, Sanktuarium św. Antoniego i klasztorze Zakonu Braci Mniejszych Konwentualnych w Warszawie, Warszawa 2010 (http://www.warszawa.franciszkanie-warszawa.pl/duszpasterstwo/wspolnoty/bractwo-sw-antoniego/). 
w Gródku Jagiellońskim; w prowincji litewskiej istniały tylko dwie kongregacje: w Grodnie i Oszmianie ${ }^{118}$.

Rozbiory Polski przyniosły trudny czas dla bractwa św. Antoniego, wtedy skończył się najbardziej dynamiczny rozwój konfraterni. Następne lata po I rozbiorze były okresem zamierania bractwa. W 3 prowincjach na terenie Polski wszystkie kongregacje św. Antoniego zostały skasowane w wyniku represji zaborców. Jedynie bractwo w Łagiewnikach zostało przywrócone w 1842 r. i dotrwało aż do okresu międzywojennego. W późniejszym okresie reaktywowano bractwo w Krakowie (1881) oraz w Sanoku (1902), ale już jako stowarzyszenie ${ }^{119}$.

\section{BIBLIOGRAFIA}

\section{Archiwum Franciszkanów w Krakowie (AFK)}

Acta Archiconfraternitatis Compassionis Jesu Christi et Beatissimae Virginis Mariae, sygn. A-VI-8. Inventarium rerum et bonorum omnium Ecclesiarum de Conventum totius Provinciae Regni Poloniae et M. D. Lithuaniae sub felici administratione A.R.P. Joannis Romartovii Artium et S.T.D. Ordinis Minorum ... Provincialis 1598 vel 1609, [b. sygn.]

Karwacki, Alojzy. Materiaty do historii polskiej i ruskiej prowincji oo. Franciszkanów, sygn. E-I-7.

Liber Confraternitatis S. Antoni, sygn. A-IV-5.

Makowski, Bonawentura. Brevis Descriptio Conventuum Provinciae Poloniae Ordinis Minorum Conventualium S.P. Francisci, 1762, [b. sygn.].

Methodus duplicis visitationis spiritualis et temporalis totius Provinciae Poloniae cura et vigilantia A.R.P. Adami Goski. 20 Iunii 1612 - 20 lunii 1615, [b. sygn.].

Visitatio localis et personalis Conventuus per P. M. Antonium Cervinum Vicarium et comissarium generalem Provinciae O.M.C. incepta AD 1618 die ultima aprilis, [b. sygn.].

\section{Archiwum Franciszkanów w Krośnie (AFKr)}

Akt erekcyjny Arcybractwa Paska św. Franciszka, sygn. A 2 pap. 1586.

Dokument fundacji Arcybractwa Męki Pańskiej, sygn. A 3 pap. 1626.

Fasc. J 1744, 1745, [b. sygn.].

Fasc. L 1785 VII, [b. sygn.].

Liber Beneficiorum Conventus Crosnensis, in quo continentur privilegia, census ac fundationes illus factus, sub regimine guardianatus P.P Fratris Leonardi Crac., Provicialatus vero A. R. P. Alberti Ghiza S. T. D. Anno D. 1628. Die XII. M. Dec., [b. sygn.].

Karwacki, Alojzy. Inwentarze i streszczenie uporzadkowanego Archiwum Konwentu OO. Franciszkanów w Krośnie, [b. sygn.].

\footnotetext{
${ }^{118}$ Synowiec, „Franciszkanie Polscy 1772-1970”, 92-94.

119 Tamże, 94-95.
} 
Odpusty dla Bractwa św. Paska, sygn. A 4 pap. 1628.

Registra acceptarum et expensarum 1616-1621, [b. sygn.].

Registra acceptarum et expensarum 1679-1685, [b. sygn.].

Registra acceptarum et expensarum 1703-1722, [b. sygn.].

\section{Archiwum Franciszkanów w Warszawie (AFW)}

Makowski, Bonawentura. Thesaurus Provinciae Poloniae O.M.S.F.C. A.D. 1764, sygn. VIII/5.

\section{Opracowania}

„Arcybractwo Paska św. Franciszka”. Wiadomości Tercjarskie 28(1936).

„Arcybractwo Paska św. Franciszka”. Pochodnia Seraficka 3(1936).

Barcik, Józef Symeon. Kalwaria Pacławska. Warszawa: Akademia Teologii Katolickiej, 1985.

Bartosiewicz, Julian. „Księga protokołów franciszkańskich prowincji ruskiej 1625-1650”. Studia Historyczne i Literackie 3(1881): 113-135.

Bruździński, Andrzej. „Bractwa religijne w siedemnastowiecznym Krakowie”. W Historia świadectwem czasów. Księdzu profesorowi Markowi Tomaszowi Zahajkiewiczowi, red. W. Bielak, S. Tylus. 103-147. Lublin: Towarzystwo Naukowe KUL, 2006.

Chiminelli, Pietro. L'umile capestro. La corda francescana. Padova: Edizioni il Messaggero di Sant'Antonio, 1957.

Codex iuris canonici auctoritate Ioannis Pauli PP. II promulgatus (25 Ianuarii 1983). W Acta Apostolicae Sedis 75(1983-II).

Encyklopedia Katolicka, t. 2, red. Feliks Gryglewicz, Romuald Łukaszyk, Zygmunt Sułowski Lublin: Towarzystwo Naukowe KUL, 1985.

Encyklopedia Katolicka, t. 5, red. Ludomir Bieńkowski, Piotr Hemperek, Stanisław Kamiński, Jerzy Misiurek, Krystyna Stawecka, Antoni Stępień, Adam Szafrański, Jan Szlaga, Anzelm Weiss. Lublin: Towarzystwo Naukowe KUL, 1989.

Estreicher, Karol. Bibliografia polska, t. XXI. Kraków: Wyd. Stanisław Estreicher, 1913.

Franchini, Giovanni. Bibliosofia e memorie letterarie di scrittori Francescani conventuali. Modena: Per gli eredi solani stampatori duch, 1693.

Kantak, Kamil. Franciszkanie polscy, t. 2. Kraków: Prowincja Polska OO. Franciszkanów, 1938.

Kuczkowski, Mirosław. „Arcybractwo Paska św. Franciszka z Asyżu w Polsce na przestrzeni wieków”. Teologia i Człowiek 22(2013), 2: 43-60.

Lelito, Stanisław. Historia klasztoru Franciszkanów w Starym Saczu (1280-1815). Kraków: Biblioteka Franciszkanów (mps), 2009.

Litak, Stanisław. „Bractwa religijne w Polsce przedrozbiorowej XIII-XVIII wiek. Rozwój i problematyka”. Przeglad Historyczny 88(1997), 3-4: 499-523.

Piasecki, Jakub. Opisanie kościołów i klasztorów księży franciszkanów (konwentualnemi zwanych): z dawnej prowincyi Polskiej Ś. Franciszka Seraficznego po utworzeniu w r. 1815 Królestwa Polskiego pozostatych / przez Jakóba Piaseckiego. Warszawa: Drukarnia J. Glücksberga, 1845.

Liricius, Hipolit. Bractwo chordy abo paska zakonnego s. Franciszka po wszytkiey Koronie Polskiey $v$ Braciey Mnieyszych Franciszka s. moca stolice apostolskiey postanowione [...]; z Sporzadzeniem 
nabożeństwa ktore zwykto bywać na mszach y processyach brackich, z niektoremi modlitwami. Kraków: W drukarniey Waleryana Piątkowskiego: [nakł. Bractwa św. Franciszka], 1646.

Prokop, Krzysztof Rafał. Poczet biskupów krakowskich. Kraków: Wyd. Św. Stanisława BM Archidiecezji Krakowskiej, 1999.

Pruszcz, Piotr. Kleynoty stotecznego miástá Krakowa, albo koscioły, y co w nich iest widzenia godnego y znácznego, przez Piotra Hiacyntha Prvszcza, krotko opisane, Powtornie záś z pilnośćia przeyźrzáne, y do druku z additámentem nowych Kośćiołow y Relikwii S. podane, z pozwoleniem Zwierzchnośći Duchowney. Kraków: W Drukarni Akademickiey, 1745.

Rejormationes generales ad clerum et populum dioecesis Cracoviensis pertinentes. Cracoviae: in Officina Andrea Petricovij 1621.

Sartori, Antonio. L'Arciconfraternita del Santo. Padova: Tip. della Provincia Patavina di S. Antonio dei Frati Minori Conventuali, 1955.

Stownik Polskich Pisarzy Franciszkańskich, red. Hieronim Wyczawski. Warszawa: Archiwum Prowincji OO. Bernardynów, 1981.

Statut Bractwa Świętego Antoniego z Padwy przy kościele Stygmatów św. Franciszka, Sanktuarium św. Antoniego i klasztorze Zakonu Braci Mniejszych Konwentualnych w Warszawie, Warszawa 2010. Dostęp: 19.01.2021, http://www.warszawa.franciszkanie-warszawa.pl/duszpasterstwo/wspol noty/bractwo-sw-antoniego/.

Synowiec, Damian. „Franciszkanie Polscy 1772-1970”. W Zakony św. Franciszka w Polsce w latach 1772-1970, t. 2, red. Joachim Bar, 4-136. Warszawa: Akademia Teologii Katolickiej, 1978.

Wróbel, Ryszard. „Dorobek kaznodziejski franciszkanów (Braci Mniejszych Konwentualnych) w Polsce w XVII i XVIII w.”. W Franciszkanie konwentualni i klaryski w Wielkopolsce od XIII do XIX wieku, 53-70. Gniezno: Muzeum Początków Państwa Polskiego, 2006.

Zwiercan, Antoni. „Bractwo Męki Pańskiej w Krakowie (1595-1795)”. Prawo Kanoniczne 26(1983), 1-2: 83-201.

Zaremska, Hanna. Bractwa w średniowiecznym Krakowie. Studium form społecznych życia religijnego. Wrocław: Ossolineum, 1977.

\section{BRACTWA W KOŚCIOŁACH FRANCISZKAŃSKICH W POLSCE W OKRESIE POTRYDENCKIM (XVI-XVIII WIEK)}

\section{Streszczenie}

W XVI wieku równocześnie z odgórną reformą trydencką rozwijał się nurt religijności tradycyjnej. Dynamizm tego nurtu religijności ludowej miał swoje źródło w późnośredniowiecznym procesie głębszego przenikania chrześcijaństwa do świadomości i życia ogółu społeczeństwa. Wyrazem tego nurtu religijnego były bractwa, które stały się jedną z form odrodzenia katolickiego w Polsce po Soborze Trydenckim. Sobór Trydencki podkreślił zasadniczą więź organizacyjną bractw z Kościołem i wyszczególnił ich specyfikę oraz poddał je bezpośredniej jurysdykcji Stolicy Apostolskiej i biskupa ordynariusza miejsca. Cechą charakterystyczną bractw była ich uniwersalność i wszechstanowość; rekrutacja członków dokonywała się z ludzi różnych stanów i zawodów ${ }^{120}$.

${ }^{120}$ Hanna Zaremska, Bractwa w średniowiecznym Krakowie. Studium form społecznych życia religijnego (Wrocław: Ossolineum, 1977), 43-45. 
Zakonnicy św. Franciszka w okresie potrydenckim poszerzyli teren swojego oddziaływania społeczno-religijnego, konsolidując przy swoich świątyniach trzy nowe, popularne, bractwa kościelne. Odzwierciedleniem tej sytuacji była świątynia franciszkańska w Krakowie, przy której powstały w XVI/XVII wieku trzy typowe dla franciszkanów bractwa: Paska św. Franciszka (1587 r.), Męki Pańskiej (1595 r.), Św. Antoniego (1664 r.). Bractwa były objęte kierownictwem duchowym zakonników franciszkańskich, korzystały z licznych przywilejów i odpustów, o które starali się zakonnicy. Działalność bractw przy kościołach franciszkańskich była charakterystycznym zjawiskiem katolickiej odnowy po Soborze Trydenckim. Franciszkanie, obok innych zakonów mendykanckich, wpisali się w ten nurt w sposób imponujący, bowiem dzięki ich zaangażowaniu i pracy integracja grup społecznych na poziomie religijnym, duchowym, kulturowym i charytatywnym przyczyniła się do odnowy Kościoła i społeczeństwa polskiego.

Słowa kluczowe: arcybractwo; bractwo; św. Franciszek z Asyżu; św. Antoni z Padwy; franciszkanie; odpusty. 